\title{
Almonds (Prunus Dulcis Mill. D. A. Webb): A Source of Nutrients and Health-Promoting Compounds
}

\author{
Davide Barreca $1, *\left(\mathbb{D}\right.$, Seyed Mohammad Nabavi ${ }^{2}$, Antoni Sureda ${ }^{3}{ }^{\circ}$, Mahsa Rasekhian ${ }^{4}$, \\ Roberto Raciti ${ }^{1}$, Ana Sanches Silva ${ }^{5,6}$ (D) Giuseppe Annunziata ${ }^{7}$ (D), Angela Arnone ${ }^{8}$, \\ Gian Carlo Tenore ${ }^{7}$ (D) İpek Süntar ${ }^{9}$ and Giuseppina Mandalari ${ }^{1}$ (D) \\ 1 Department of Chemical, Biological, Pharmaceutical and Environmental Sciences, University of Messina, \\ 98168 Messina, Italy; rraciti@unime.it (R.R.); gmandalari@unime.it (G.M.) \\ 2 Applied Biotechnology Research Center, Baqiyatallah University of Medical Sciences, \\ Tehran 14359-16471, Iran; nabavi208@gmail.com \\ 3 Research Group on Community Nutrition and Oxidative Stress (NUCOX), Health Research Institute of the \\ Balearic Islands (IdISBa), and CIBEROBN (Physiopathology of Obesity and Nutrition CB12/03/30038), \\ University of Balearic Islands, Palma de Mallorca, E-07122 Balearic Islands, Spain; tosugo@hotmail.com \\ Pharmaceutical Sciences Research Center, Health Institute, Kermanshah University of Medical Sciences, \\ Kermanshah 6734667149, Iran; mahsarasekhian@gmail.com \\ 5 National Institute for Agricultural and Veterinary Research (INIAV), Rua dos Lágidos, Lugar da Madalena, \\ 4485-655 Vila do Conde, Portugal; anateress@gmail.com \\ 6 Center for Study in Animal Science (CECA), ICETA, University of Oporto, 4051-401 Oporto, Portugal \\ 7 Department of Pharmacy, University of Naples Federico II, Via Domenico Montesano 49, 80131 Naples, Italy; \\ giuseppe.annunziata@unina.it (G.A.); giancarlo.tenore@unina.it (G.C.T.) \\ 8 Dipartimento di Medicina Clinica e Chirurgia, Unit of Endocrinology, Federico II University Medical School \\ of Naples, Via Sergio Pansini 5, 80131 Naples, Italy; angela.arnone15@gmail.com \\ 9 Department of Pharmacognosy, Faculty of Pharmacy, Gazi University, 06330 Etiler Ankara, Turkey; \\ ipesin@gazi.edu.tr \\ * Correspondence: dbarreca@unime.it; Tel.: +39-0906765187; Fax: +39-0906765186
}

Received: 27 January 2020; Accepted: 26 February 2020; Published: 1 March 2020

\begin{abstract}
Almonds (Prunus dulcis Miller D. A. Webb (the almond or sweet almond)), from the Rosaceae family, have long been known as a source of essential nutrients; nowadays, they are in demand as a healthy food with increasing popularity for the general population and producers. Studies on the composition and characterization of almond macro- and micronutrients have shown that the nut has many nutritious ingredients such as fatty acids, lipids, amino acids, proteins, carbohydrates, vitamins and minerals, as well as secondary metabolites. However, several factors affect the nutritional quality of almonds, including genetic and environmental factors. Therefore, investigations evaluating the effects of different factors on the quality of almonds were also included. In epidemiological studies, the consumption of almonds has been associated with several therapeutically and protective health benefits. Clinical studies have verified the modulatory effects on serum glucose, lipid and uric acid levels, the regulatory role on body weight, and protective effects against diabetes, obesity, metabolic syndrome and cardiovascular diseases. Moreover, recent researchers have also confirmed the prebiotic potential of almonds. The present review was carried out to emphasize the importance of almonds as a healthy food and source of beneficial constituents for human health, and to assess the factors affecting the quality of the almond kernel. Electronic databases including PubMed, Scopus, Web of Science and SciFinder were used to investigate previously published articles on almonds in terms of components and bioactivity potentials with a particular focus on clinical trials.
\end{abstract}

Keywords: almonds; secondary metabolites; health-promoting properties; almond composition; clinical trials 


\section{Introduction}

The almond (Prunus dulcis (Mill.) D. A. Webb) is an important nut native to Central Asia, but today is produced worldwide in hot-arid Mediterranean climate regions [1]. Nowadays, the USA is the largest almond producer, followed by Spain and Australia. Cultivated almond varieties display a different chemical profile due to genetic and ecological factors, as well as processing conditions. Regular consumption of nuts has been related to healthy effects, especially against cardiometabolic diseases $[2,3]$. Epidemiological studies and clinical trials have reported positive effects of nuts consumption against a significant number of pathologies such as obesity, hypertension, diabetes mellitus and metabolic syndrome [4-6]. In addition, individuals who consume nuts regularly present lower waist circumference and improved metabolic profiles [7]. The almond kernel, which constitutes the edible part, is a seed formed by two large cotyledons covered by a brown skin and protected by an external hull with an intermediate shell [8]. Once maturity is reached, the hull opens and the seed separates easily. Almonds contain lipids (around 50\%), proteins (around 25\%) and carbohydrates (around 20\%), and have a low moisture content and diverse minor bioactive compounds. The beneficial effects of almond consumption are associated with its composition of macro- and micronutrients. Among the compounds with beneficial properties for health, the lipid profile, predominantly monounsaturated fatty acids (MUFA, 60\%), followed by polyunsaturated fatty acids (PUFA, 30\%), fiber, vitamins, minerals, phytosterols and polyphenols, can be highlighted $[9,10]$. The great diversity of varieties as well as the forms of cultivation and the climatic characteristics determine the remarkable differences in almonds' chemical composition [11]. In addition, the form of consumption, mostly raw or roasted, adds additional changes to the composition of almonds. The roasting process induces chemical and microstructural changes, especially altering the lipid composition, favoring its oxidation and modifying antioxidant compounds [12,13]. Moreover, the use of prebiotics to promote gut microbiota modulation towards a health-promoting profile is gaining attention. The fiber and polyphenols content in almonds could be a substrate for microbial fermentation in the gut, contributing to regulation of the microbiota composition [14,15]. Considering the relevance of almonds from an agro-economical and nutritional point of view, the present review addresses the chemical composition of different almond varieties, the bioavailability and metabolism of its components, especially bioactive compounds, and their use as a source of functional foods and prebiotics.

\section{Food Composition of the Different Varieties}

Almonds are tree nuts recognized as a healthy snack and known to be a good source of protein, monosaturated fatty acids, dietary fiber (insoluble/soluble fiber at 4:1), vitamin E, riboflavin and essential minerals (manganese, magnesium, copper and phosphorus) (Tables 1-3) [16,17]. Daily intake of 30-50 $\mathrm{g}$ is recommended as part of a healthy diet [18]. Generally, in an almond orchard, rows of one variety alternate with one or more rows of other varieties. The selection of the variety depends on the yield, performance of the field in specific regions, resistance to disease, and marketability [17]. The state of California in the United States is one of the main regions of the world producing almonds (around $80 \%$ of the world's almonds). About 30 varieties of almonds are commercialized in California, but only 10 account for most of the production. The most important variety in terms of production and marketing is Nonpareil, due to their excellent tree and nut characteristics [17]. Table 1 summarizes the variability in the nutrient composition of different varieties of almonds. Moreover, it includes the data from two food composition databases, the U.S. Department of Agriculture (USDA) National Nutrient Database for Standard Reference [19] and the Portuguese Food Composition Database (TCA) [20]. National food composition databases, and especially the USDA include the representative values of the almond nutrients found in the national food supply [17]. Some of the differences may be influenced by the water content (3.1-6.5 g/100 g fresh weight) (Table 1), which is related to the nut maturity and harvest and storage conditions [17]. Some of the factors that most affect the variability among almond varieties are genetic, environmental (location, ecological conditions, technical and cultural practices) and analytical [21]. The quality of almonds is generally defined by the water content, lipid content, oil 
composition and oil ultraviolet absorption coefficients [22]. Therefore, some studies have evaluated the effect of different factors on the kernel quality of almonds. Piscopo et al. [22] studied the effect of harvest time (beginning and end of August) on the fatty acid and mineral contents of different almond varieties. During ripening, an increase in fat and acidic content was observed, and Mas Bovera showed the highest nutritional value. Kazantzis et al. [23] studied the effect of harvest time and storage conditions on two varieties of almonds, Ferragnes and Texas. They concluded that early harvest almonds presented higher moisture, better oil quality and lower sugar content than late harvested almonds. Therefore, they have a higher quality but lower sweetness. Summo et al. [24] also studied the influence of harvest time and cultivar and concluded that harvest time increased the lipid content and decreased the carbohydrates and protein content. Almonds present a similar overall nutrient profile even when comparing different varieties, year of production and growing regions (Tables 1-5). Gama et al. [18] found there were no significant differences in the aluminum, iron, calcium, phosphorus, magnesium, zinc and sodium amount among brands of almond kernels, but the amounts of proteins, potassium, copper, boron, sulfur and manganese were significantly different (Tables 1 and 2). Moreover, Yada et al. [17] concluded that the difference in mean protein, total lipids, fatty acids and dietary fiber was less than 1.2-fold amongst the seven different almond varieties studied. The highest differences among varieties were found for riboflavin (1.7-fold differences). Almond proteins are recognized to present a high arginine content (Table 5) and good digestibility [16]. Approximately 50\% of the almond weight is fat, mostly MUFA, which are associated with the reduction of low-density lipoprotein cholesterol (LDL-c) (Table 1). Therefore, almonds are associated with benefits for cardiovascular health and obesity-related diseases. On the other hand, they may pose a risk for potentially allergic individuals. In a study carried out by Yada et al. [17], the content on $\beta$-sitosterol, stigmasterol and campesterol was evaluated in seven almond varieties from the top 10 almond varieties in California and they ranged between 103-206, 1.3-9.8 and 4.1-11.8 mg/100 g, respectively. Summo et al. [24] also studied the antioxidant activity and total phenolic compounds of 10 almond cultivars and found a great variability influenced by the genotype. Also, late harvest increased antioxidant activity, suggesting that antioxidant compounds develop in the late stage of ripening. 
Table 1. Nutritional composition (g/100 g) of different varieties of almonds (Prunus dulcis Mill. D. A. Webb).

\begin{tabular}{|c|c|c|c|c|c|c|c|c|c|c|c|c|c|c|c|c|c|c|c|c|c|c|}
\hline Variety & $\begin{array}{l}\text { है } \\
\text { है } \\
\text { है }\end{array}$ & $\begin{array}{l}\tilde{z} \\
\tilde{z} \\
\text { है }\end{array}$ & 壱 & & & 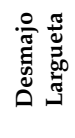 & 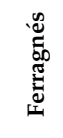 & 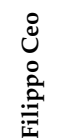 & 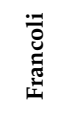 & $\stackrel{N}{ \pm}$ & نัّ & 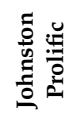 & $\begin{array}{l}\tilde{\Xi} \\
\tilde{\Xi} \\
\Sigma\end{array}$ & & & 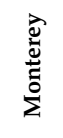 & & & 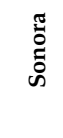 & 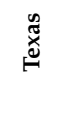 & 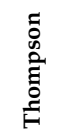 & $\stackrel{\circ}{\stackrel{0}{ٍ ~}}$ \\
\hline Water & 4.4 & 4.9 & 4.7 & 3.1 & 4.1 & 5.7 & 6.5 & 5.4 & 5.7 & 4.6 & 6.5 & 5.4 & 6.1 & 4.3 & 4.6 & 3.9 & 4.0 & 3.9 & 4.1 & 6.5 & 5.3 & 5.3 \\
\hline Protein & 21.2 & 21.6 & 20.5 & 20.6 & 20.2 & 19.6 & 18.1 & 14.1 & 20.5 & 22.5 & 21.5 & 20.2 & 22.1 & 23.3 & 20.9 & 21.3 & 21.0 & 20.2 & 22.4 & 20.1 & 21.2 & 20.5 \\
\hline Total lipids & 49.9 & 56.0 & 50.0 & 47.5 & 50.1 & 50.6 & 50.1 & 56.2 & 44.3 & 48.4 & 42.4 & 47.0 & 52.7 & 44.1 & 49.6 & 49.4 & 43.3 & 49.6 & 50.2 & 48.8 & 48.0 & 47.3 \\
\hline SFA & & & 4.1 & & 3.9 & & & & & 3.4 & & & & & 3.7 & 3.7 & & 3.8 & 3.9 & & & \\
\hline MUFA & & & 29.4 & & 29.7 & & & & & 30.5 & & & & & 31.6 & 32.3 & & 31.3 & 31.4 & & & \\
\hline PUFA & & & 13.9 & & 13.8 & & & & & 12.0 & & & & & 11.6 & 11.2 & & 11.7 & 12.4 & & & \\
\hline Ash & 3.0 & 3.0 & 2.8 & 3.7 & 2.9 & 3.2 & 2.9 & 2.5 & 3.5 & 2.9 & 3.0 & 2.6 & 3.4 & 4.6 & 3.0 & 3.0 & 4.5 & 2.9 & 3.0 & 2.9 & 3.1 & 3.0 \\
\hline Fiber & 12.5 & 12.0 & 12.2 & & 12.5 & & & & & 11.0 & & & & & 13.5 & 11.8 & & 12.9 & 11.8 & & & \\
\hline Sugars & 4.4 & & & 5.4 & & & & & & & & & & 6.2 & & & 7.5 & & & & & \\
\hline References & [19] & [20] & [17] & [25] & [17] & [24] & [24] & [24] & [24] & [17] & [24] & [24] & [24] & [25] & [17] & [17] & [25] & [17] & [17] & [24] & [24] & {$[24]$} \\
\hline
\end{tabular}

Table 2. Mineral composition (mg/100 g) of different varieties of almonds (Prunus dulcis Mill. D. A. Webb).

\begin{tabular}{|c|c|c|c|c|c|c|c|c|c|c|c|c|c|c|c|c|c|c|c|c|c|c|}
\hline Variety & $\begin{array}{l}\text { है } \\
\text { ह } \\
\text { है } \\
\text { है }\end{array}$ & $\begin{array}{l}\text { है } \\
\text { ह } \\
\text { है }\end{array}$ & 妾 & 善 & 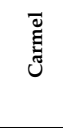 & 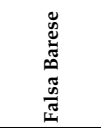 & 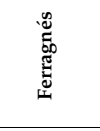 & 营 & 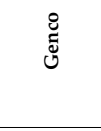 & 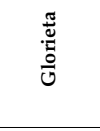 & 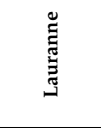 & 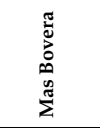 & 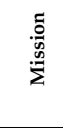 & 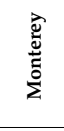 & 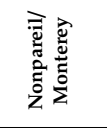 & $\begin{array}{l}\overline{\overline{\tilde{w}}} \\
\overline{0} \\
\overline{\tilde{z}} \\
z\end{array}$ & 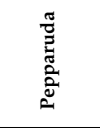 & 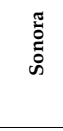 & 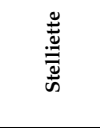 & 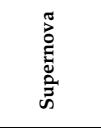 & 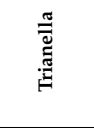 & 题 \\
\hline $\begin{array}{c}\text { Aluminum (Al) } \\
\text { Boron (B) }\end{array}$ & & & $\begin{array}{l}0.39 \\
1.85\end{array}$ & & & & & & & & & & & & & & & & & & & \\
\hline Calcium (Ca) & 269 & 270 & 200 & 288 & 279 & 137-142 & $128-138$ & 290 & 138 & 90-102 & $166-176.5$ & $103-129$ & 330 & 252 & $172-252$ & 261 & 18-131 & 234 & 55-176 & $113-127$ & $106-125$ & $106-127$ \\
\hline Iron $(\mathrm{Fe})$ & 3.7 & 4 & 3.22 & 3.27 & 3.27 & 3.13-4.45 & 3.42-4.48 & 3.63 & $1.82-4.29$ & $4.36-6.10$ & $4.45-4.97$ & $1.56-4.73$ & 3.34 & 3.58 & & 3.47 & $2.84-3.45$ & 3.84 & .09-4.27 & $5.54-6.49$ & $2.80-5.38$ & $2.71-5.11$ \\
\hline Magnesium (Mg) & $\begin{array}{l}270 \\
48\end{array}$ & 260 & $\begin{array}{l}300 \\
500\end{array}$ & $\begin{array}{l}263 \\
463\end{array}$ & 262 & $235-254$ & $226-233$ & 260 & 254-235 & $245-249$ & 154-246 & $256-276$ & $\begin{array}{l}272 \\
512\end{array}$ & 278 & $\begin{array}{l}121-145 \\
101-258\end{array}$ & 275 & $223-246$ & 256 & $241-249$ & $218-234$ & $226-241$ & $222.5-225.5$ \\
\hline $\begin{array}{l}\text { Phosphorus (P) } \\
\text { Potassium (K) }\end{array}$ & $\begin{array}{l}481 \\
733\end{array}$ & $\begin{array}{l}110 \\
860\end{array}$ & 600 & $\begin{array}{l}463 \\
664\end{array}$ & $\begin{array}{l}462 \\
679\end{array}$ & $690-726$ & $661-695$ & $\begin{array}{l}466 \\
664\end{array}$ & $572-674$ & $694-727$ & $652-737$ & $733-786$ & $\begin{array}{l}512 \\
724\end{array}$ & $\begin{array}{l}524 \\
766\end{array}$ & $\begin{array}{l}191-20-38 \\
1550-2370\end{array}$ & $\begin{array}{l}455 \\
762\end{array}$ & 729-745 & $\begin{array}{l}526 \\
773\end{array}$ & $699-794$ & $659-672$ & $525-727$ & $676-741$ \\
\hline Sodium (Na) & 1 & 6 & 3.54 & & & & & & & $694-727$ & $652-737$ & $700=700$ & & & & & $2 y=-45$ & & $699-794$ & $659-6 / 2$ & $525-727$ & $8 / 0-/ 41$ \\
\hline $\begin{array}{l}\text { Sulphur (S) } \\
\text { Zinc (Zn) }\end{array}$ & 3.1 & 3.1 & $\begin{array}{l}200 \\
213\end{array}$ & 2.98 & & & $3.71-4.89$ & & $3.95-4.69$ & $4.66-5.55$ & $4.45-5.93$ & $3.88-5.46$ & & & & 3.23 & 1.08 & 3.8 & $37-553$ & & $438-537$ & \\
\hline Copper $(\mathrm{Cu})$ & 1 & & 0.89 & $\begin{array}{l}2.90 \\
0.92\end{array}$ & 1.09 & $\begin{array}{l}2.05-3.01 \\
1.98-3.38\end{array}$ & $2.14-3.80$ & $\begin{array}{l}2.02 \\
0.85\end{array}$ & $\begin{array}{l}0.90-4.09 \\
1.83-3.90\end{array}$ & $\begin{array}{l}.4 .00-3.000 \\
1.93-3.85\end{array}$ & $\begin{array}{l}4.40-1.930 \\
2.18-3.76\end{array}$ & $\begin{array}{l}.000-3.40 \\
1.68-3.82\end{array}$ & $\begin{array}{l}2.10 \\
0.72\end{array}$ & 0.94 & & 1.05 & 2.27 & $\begin{array}{l}0.0 \\
0.9\end{array}$ & $\begin{array}{l}4.37-5.53 \\
1.76-3.72\end{array}$ & $\begin{array}{l}3.25-5-30 \\
2.16-89\end{array}$ & $\begin{array}{l}4.38-5.37 \\
2.06-3.74\end{array}$ & $\begin{array}{c}4.3-5.1 \\
204-3.58\end{array}$ \\
\hline $\begin{array}{c}\text { Manganese (Mn) } \\
\text { Selenium (Se) }\end{array}$ & $\begin{array}{c}2.2 \\
4.1 \times 10^{-3}\end{array}$ & & 2.56 & 2 & 2.14 & $1.01-1.27$ & $1.04-1.46$ & 2.08 & $1.16-1.29$ & $1.11-1.12$ & $1.22-1.44$ & 1.39 & 2.2 & 2.12 & & 2.21 & $0.89-0.95$ & 3.04 & $1.21-1.32$ & $0.93-1.26$ & $1.16-1.20$ & $1.21-1.38$ \\
\hline Units & $\begin{array}{c}\mathrm{mg} / \\
100 \mathrm{~g} \mathrm{FW}\end{array}$ & $\begin{array}{c}\mathrm{mg} / \\
100 \mathrm{~g} \mathrm{FW}\end{array}$ & $\begin{array}{r}\mathrm{mg} / \\
100 \mathrm{~g}\end{array}$ & $\begin{array}{c}\mathrm{mg} / \\
100 \mathrm{~g} \\
\mathrm{FW}\end{array}$ & $\begin{array}{c}\mathrm{mg} / \\
100 \mathrm{~g} \\
\mathrm{FW}\end{array}$ & $\begin{array}{c}\mathrm{mg} / \\
100 \mathrm{~g} \\
\mathrm{DW}\end{array}$ & $\begin{array}{c}\mathrm{mg} / \\
100 \mathrm{~g} \\
\mathrm{DW}\end{array}$ & $\begin{array}{c}\mathrm{mg} / \\
100 \mathrm{~g} \\
\mathrm{FW}\end{array}$ & $\begin{array}{c}\mathrm{mg} / \\
100 \mathrm{~g} \\
\mathrm{DW}\end{array}$ & $\begin{array}{c}\mathrm{mg} / \\
100 \mathrm{~g} \\
\mathrm{DW}\end{array}$ & $\begin{array}{c}\mathrm{mg} / \\
100 \mathrm{~g} \\
\mathrm{DW}\end{array}$ & $\begin{array}{c}\mathrm{mg} / \\
100 \mathrm{~g} \\
\mathrm{DW}\end{array}$ & $\begin{array}{c}\mathrm{mg} / \\
100 \mathrm{~g} \\
\mathrm{FW}\end{array}$ & $\begin{array}{c}\mathrm{mg} / \\
100 \mathrm{~g} \\
\mathrm{FW}\end{array}$ & $\begin{array}{r}\mathrm{mg} / \\
100 \mathrm{~g}\end{array}$ & $\begin{array}{c}\mathrm{mg} / \\
100 \mathrm{~g} \\
\mathrm{FW}\end{array}$ & $\begin{array}{c}\mathrm{mg} / \\
100 \mathrm{~g} \\
\mathrm{DW}\end{array}$ & $\begin{array}{c}\mathrm{mg} / \\
100 \mathrm{~g} \\
\mathrm{FW}\end{array}$ & $\begin{array}{r}\mathrm{mg} / \\
100 \mathrm{~g} \\
\mathrm{DW}\end{array}$ & $\begin{array}{c}\mathrm{mg} / \\
100 \mathrm{~g} \\
\mathrm{DW}\end{array}$ & $\begin{array}{c}\mathrm{mg} / \\
100 \mathrm{~g} \\
\mathrm{DW}\end{array}$ & $\begin{array}{c}\mathrm{mg} / \\
100 \mathrm{~g} \mathrm{DW}\end{array}$ \\
\hline Reference & [19] & [20] & {$[18]$} & {$[17]$} & {$[17]$} & [22] & [22] & [17] & [22] & [22] & [22] & [22] & [17] & {$[17]$} & [26] & {$[17]$} & [22] & {$[17]$} & 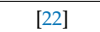 & [22] & [22] & [22] \\
\hline
\end{tabular}


Table 3. Vitamin content (per $100 \mathrm{~g}$ ) of different varieties of almonds (Prunus dulcis Mill. D. A. Webb).

\begin{tabular}{|c|c|c|c|c|c|c|c|c|c|c|}
\hline $\begin{array}{ll}\text { Nutrients } & \text { Variety } \\
\end{array}$ & Unknown & Unknown & Butte & Carmel & Fritz & Mission & Monterey & Nonpareil & Sonora & Units \\
\hline Thiamin & 0.205 & 0.21 & & & & & & & & $\mathrm{mg}$ \\
\hline Riboflavin & 1.138 & 0.75 & 1.68 & 1.17 & 1.01 & 1.11 & 1 & 1.32 & 1.25 & $\mathrm{mg}$ \\
\hline Pantothenic acid & 0.471 & & & & & & & & & $\mathrm{mg}$ \\
\hline Vitamin B6 & 0.137 & 0.15 & & & & & & & & $\mathrm{mg}$ \\
\hline Total folate & 44 & 49 & & & & & & & & $\mu \mathrm{g}$ \\
\hline Vitamin E & 25.63 & 24 & 27.6 & 29.9 & 26.3 & 28.3 & 21.9 & 26 & 31 & $\mathrm{mg}$ \\
\hline References & [19] & [20] & & & & [17] & & & & \\
\hline
\end{tabular}

Table 4. Sugar content of different varieties of almonds (Prunus dulcis Mill. D. A. Webb).

\begin{tabular}{|c|c|c|c|c|c|c|c|c|c|c|c|c|}
\hline \multirow{2}{*}{ Almond Varieties } & \multicolumn{4}{|c|}{ Sucrose } & \multicolumn{2}{|c|}{ Raffinose } & \multicolumn{2}{|c|}{ Glucose } & \multicolumn{2}{|c|}{ Fructose } & \multirow{2}{*}{$\begin{array}{c}\text { Maltose } \\
\text { g/100 g DW }\end{array}$} & \multirow{2}{*}{$\begin{array}{l}\text { Inositol } \\
\% \text { DW }\end{array}$} \\
\hline & $\mathrm{g} / \mathbf{1 0 0} \mathrm{g} \mathrm{FW}$ & $\mathrm{g} / 100 \mathrm{~g}$ DW & \% DW & $\mathrm{g} / 100 \mathrm{~g} \mathrm{FW}$ & $\mathrm{g} / 100 \mathrm{~g}$ DW & \% DW & $\mathrm{g} / 100 \mathrm{~g}$ DW & $\mathrm{g} / 100 \mathrm{~g}$ DW & $\mathrm{g} / 100 \mathrm{~g}$ DW & $\mathrm{g} / 100 \mathrm{~g}$ DW & & \\
\hline Butte & & & & 3.1 & & & & & & & & \\
\hline Carmel & & & & 3.4 & & & & & & & & \\
\hline Casanova & 13.9 & & & & 1.93 & & 0.96 & & 0.24 & & & \\
\hline Duro italiano & 13.2 & & & & 2.11 & & 1.11 & & 0.27 & & & \\
\hline Ferraduel & 16.3 & & & & 0.71 & & 0.95 & & 0.38 & & & \\
\hline Ferragnes & 22.2 & & $70.6-85.3$ & & 0.75 & $1.23-4.84$ & 1.47 & & 0.37 & & & $2.35-7.96$ \\
\hline Ferrastar & 22.0 & & & & 1.73 & & 1.04 & & 0.17 & & & \\
\hline Fritz & & & & 3 & & & & & & & & \\
\hline Gloriette & 16.9 & & & & 0.89 & & 1.3 & & 0.59 & & & \\
\hline Marcona & 11.5 & & & & 1.67 & & 0.77 & & 0.29 & & & \\
\hline Mission & & & & 2.9 & & & & & & & & \\
\hline Monterey & & & & 3.7 & & & & & & & & \\
\hline Nonpareil & & & & 4.1 & & & & & & & & \\
\hline Pegarinhos (one seed) & 12.0 & & & & 1.43 & & 0.71 & & 0.19 & & & \\
\hline Pegarinhos (two seeds) & 15.9 & & & & 1.29 & & 0.42 & & 0.11 & & & \\
\hline Refego & 14.7 & & & & 1.4 & & 0.68 & & 0.25 & & & \\
\hline Sonora & & & & 3.1 & & & & & & & & \\
\hline Sweet kernelled & & 2.53 & & & & & & 1.88 & & 4.08 & 0.92 & \\
\hline $\begin{array}{l}\text { almond selections } \\
\text { Bitter kernelled almond }\end{array}$ & & $\begin{array}{c}(1.27-3.70) \\
2.52\end{array}$ & & & & & & $\begin{array}{c}(1.00-4.30) \\
2.24\end{array}$ & & $\begin{array}{c}(1.42-6.50) \\
2.98\end{array}$ & $\begin{array}{c}(0.29-1.50) \\
0.79\end{array}$ & \\
\hline $\begin{array}{l}\text { selections } \\
\text { s }\end{array}$ & & $(0.99-4.35)$ & & & & & & $(1.18-4.40)$ & & $(1.60-4.46)$ & $(0.18-1.30)$ & \\
\hline Reference & [27] & [28] & [23] & [17] & [27] & [23] & [27] & {$[28]$} & [27] & [28] & {$[28]$} & [23] \\
\hline
\end{tabular}

DR—dry weight; FW—fresh weight. 
Table 5. Amino acid content of different varieties of almonds (Prunus dulcis Mill. D. A. Webb).

\begin{tabular}{|c|c|c|c|c|}
\hline Amino Acids & $\begin{array}{c}\text { Almond } \\
\text { (g/100 g protein) }\end{array}$ & Carmel & Mission & Nonpareil \\
\hline Histidine & 0.539 & 1.93 & 1.93 & 2.14 \\
\hline Isoleucine & 0.751 & 2.88 & 2.83 & 2.71 \\
\hline Leucine & 1.473 & 6.19 & 5.77 & 5.81 \\
\hline Lysine & 0.568 & 2.14 & 1.99 & 2.36 \\
\hline Methionine & 0.157 & 0.4 & 0.37 & 0.42 \\
\hline Cystine & 0.215 & 0.26 & 0.28 & 0.24 \\
\hline Threonine & 0.601 & 1.95 & 1.91 & 1.93 \\
\hline Tryptophan & 0.211 & 1.08 & 0.89 & 0.89 \\
\hline Valine & 0.855 & 3.39 & 3.3 & 3.17 \\
\hline Phenylalanine & 1.132 & 4.38 & 4.1 & 4.25 \\
\hline Tyrosine & 0.45 & 1.51 & 1.39 & 1.19 \\
\hline Arginine & 2.465 & 9.4 & 9.68 & 9.33 \\
\hline Alanine & 0.999 & 4.25 & 4.12 & 4.11 \\
\hline Reference & [19] & [25] & [25] & [25] \\
\hline
\end{tabular}

\section{Main Almond Polyphenols}

Polyphenols are concentrated at the lipid interface to the environment, where they are responsible for the almond quality, contributing to the properties and increasing the shelf life. Based mainly on high performance liquid chromatography-diode array- mass spectrometry detection (HPLC-DAD-MS) and gas chromatography-mass spectrometry (GC-MS) separation techniques, numerous polyphenols ( $\sim 312 \mathrm{mg} / 100 \mathrm{~g}$ of almond) have been identified in whole almonds, but also in almond blanch water, almond skins and almond hulls [29-32]. Among polyphenols, the most abundant were hydrolysable tannins, proanthocyanidins and flavonoids (Figure 1), independently of the almond's nature (roasted or raw), the cultivar, the cultivation techniques and the environmental factors, ranging from 61 to $162 \mathrm{mg} / 100 \mathrm{~g}$ of almonds. Phenolic acids, lignans, isoflavones and stilbenes (Figure 1) were identified in lesser, but always significant, amounts ranging from 0.7 to $5.5 \mathrm{mg} / 100 \mathrm{~g}$ of almonds. Almond proanthocyanidins are mainly characterized by B-type interflavan bonding (with carbon-carbon bonds at $\mathrm{C} 4 \rightarrow \mathrm{C} 6$ or $\mathrm{C} 4 \rightarrow \mathrm{C} 8)$, based on regular repetition of (-)-epicatechin and (+)-catechin, and, in minor amounts, of (-)-epiafzelechin [29]. These basic elements can be further modified by galloylation or polygalloylation $[33,34]$. A-type proanthocyanidins have been reported, but they have not been well characterized [29]. Almonds are rich in proanthocyanidin polymers, but B-type (procyanidin B1, B2, B3, B5, B7) and A-type dimers, B-type oligomers, and mixed B-/A-type oligomers have also been identified by normal-phase high performance liquid chromatography (HPLC) analysis, high performance liquid chromatography-mass spectrometry (HPLC-MS) methods and matrix-assisted laser desorption/ionization (MALDI) analysis [33-37]. Among the hydrolysable tannins, ellagitannins, gallotannins and ellagic acid have been separated and identified in almonds, with contents ranging from $53-57,20-34$ to $\sim 0.51 \mathrm{mg} / 100 \mathrm{~g}$, respectively $[38,39]$. 


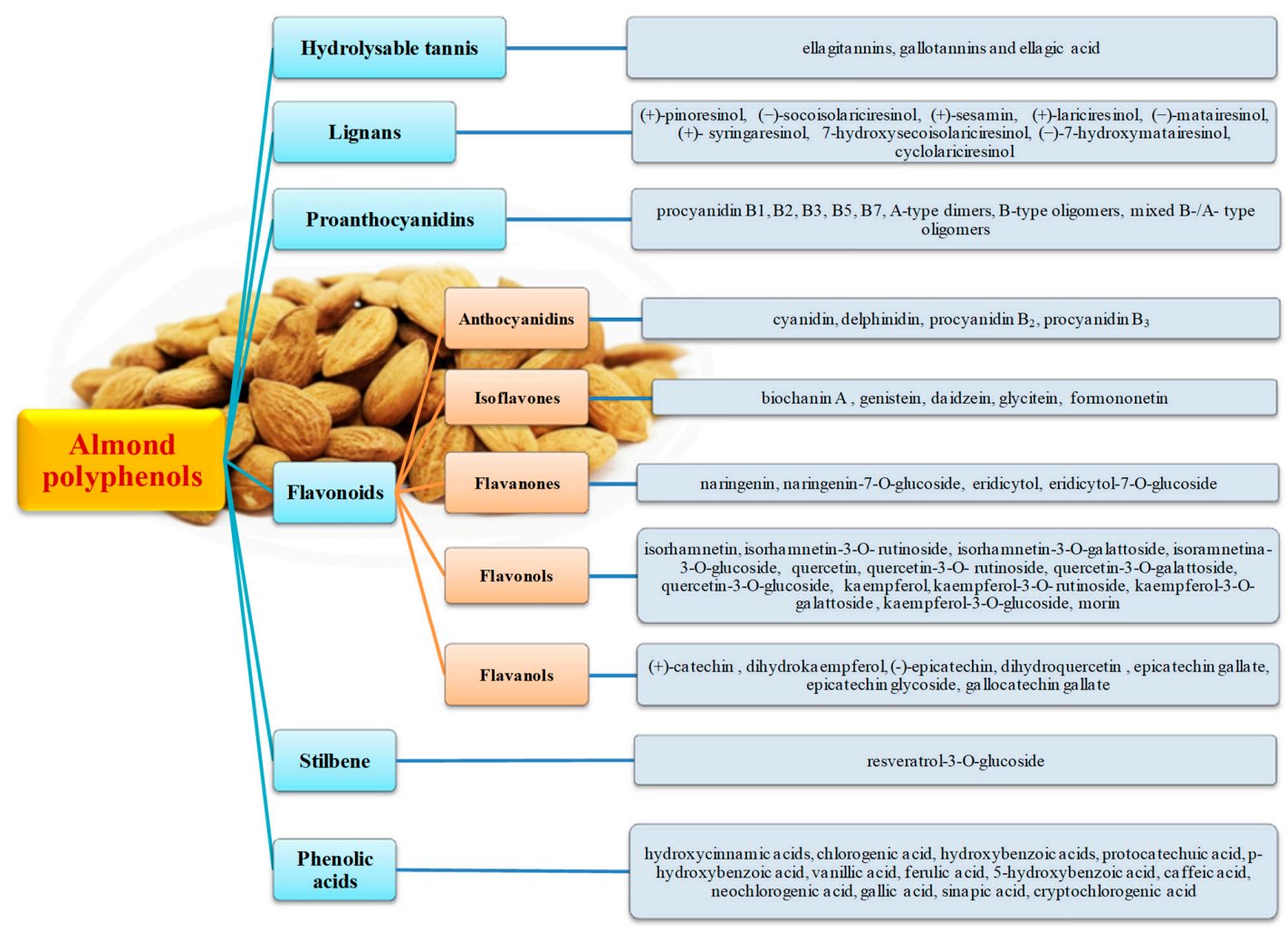

Figure 1. Main polyphenols present in whole almonds.

Different classes of flavonoids have been reported in almonds or their coproducts, including flavonols, anthocyanidins (cyanidin), flavanones and flavan-3-ols. Among the flavan-3-ols, (+)-catechin, dihydrokaempferol, and (-)-epicatechin were the most abundant molecules, ranging from 2 to $40 \mathrm{mg} / 100 \mathrm{~g}$ of almond, but, although in minor amounts, dihydroquercetin, gallocatechin gallate, epicatechin gallate and epicatechin glycoside have also been reported [29,40]. Flavonols are, by far, the most abundant flavonoid class in almonds (ranging from 87 to $135 \mathrm{mg} / 100 \mathrm{~g}$ ) and include kaempferol, quercetin, isorhamnetin and their 3-O-glucosides, rutinosides and galactosides and morin [41,42]. Isorhamnetin and its derivatives are the most abundant compounds, followed by kaempferol and quercetin derivates. Naringenin and its 7-O-glucoside derivatives are the main flavanones identified in whole almonds ( $\sim 3 \mathrm{mg} / 100 \mathrm{~g})$, while eridicytol-7-O-glucoside is present in almond skin and blanch water. Several different phenolic acids and aldehydes (ranging from 5 to $12 \mathrm{mg} / 100 \mathrm{~g}$ ) have been reported in whole almonds, such as hydroxycinnamic acids, chlorogenic acid, hydroxybenzoic acids, protocatechuic acid, $p$-hydroxybenzoic acid, vanillic acid, ferulic acid, 5-hydroxybenzoic acid, caffeic acid, neochlorogenic acid, sinapic acid and cryptochlorogenic acid [43,44]. Limited information is available on isoflavones, lignans and stilbenes, with the identification, in most cases, of aglycone structures, after chemical or enzymatic hydrolysis, but it is possible that these structures are present in the glycosylated forms as well as involved in the formation of more complex structures in the natural matrix. Although some isoflavones have been quantified in whole almonds ( $40 \mu \mathrm{g} / 100 \mathrm{~g})$, several derivates have been identified by high performance liquid chromatography-mass spectrometry (HPLC-MS) and gas chromatography-mass spectrometry GC-MS, including biochanin A (by far the most abundant derivative $\sim 25 \mu \mathrm{g} / 100 \mathrm{~g}$ ), genistein, daidzein, glycitein and formononetin [45]. Resveratrol-3-O-glucoside is the main stilbene identified and quantified, while, after hydrolysis, a combination of GC-MS and HPLC-MS/MS analysis has led to the identification of the following lignans: (+)-pinoresinol, (-)-socoisolariciresinol, (+)-sesamin, (+)-lariciresinol, (-)-matairesinol, (+)syringaresinol, 7-hydroxysecoisolariciresinol, (-)-7-hydroxymatairesinol and cyclolariciresinol in a total amount of $\sim 670 \mu \mathrm{g} / 100 \mathrm{~g}[45,46]$. 


\section{Bioavailability and Metabolism of Almond Components}

Almonds contain several compounds with remarkable functions in the human body. They are rich sources of carbohydrates (mainly dietary fiber), fatty acids, proteins and amino acids, as well as vitamins, minerals and secondary metabolites. Mastication has a significant impact on the following phases of digestion, although other factors can also influence the process. Experiments performed in vivo on pigs showed no significant statistical differences in the plasma glucose or lipid amount or in particle sizes and rheological behavior during gastric digestion between raw and roasted almonds [47,48], although the authors noticed a more rapid gastric emptying of protein in pigs for raw than roasted almonds due the process of protein segregation. Moreover, recently, Grundy et al. [49] detected negligible differences, during the duodenal phase, in the release of lipid in the gastric compartment and during the time course of lipid digestion [50] between the masticated bolus of roasted almonds and raw almonds. In the first phase of digestion, the particle size plays a substantial role in the release of the components for their absorption and metabolization. In fact, from proteins to carbohydrates and lipids, mastication itself has an effect on nutrient digestion and absorption in the gut, on weight management, hormone release and satiety. Mandalari et al. [51] provided a possible mechanism for incomplete nutrient absorption in the gut, due to the presence of almond cell walls that prevent lipid release from intact cells, Moreover, recent researchers have shown the fundamental role of almond cell walls in the regulation of almond components, postprandial lipemia and glycemia and of consequences in the attenuation, for instance, of cardiovascular disease risk. Almonds are rich sources of polyphenols, which are metabolized remarkably after their ingestion, and the bioavailability of these compounds significantly influences the health-promoting properties of this matrix as well as of its co-products and derivatives. In fact, the metabolization of polyphenols may result in the production of different classes of metabolites that, often, may have more interesting biological activities than their dietary natural precursor. Almond tannins, for instance, are mainly utilized and transformed by the gut microbiota, producing valerolactone intermediates and hydroxybenzoic acids after the metabolization of proanthocyanidins (Figure 2). Following this metabolization, the products are released from the gut microbiota, absorbed and submitted to enzymatic transformation to produce hydroxyl, glucuronic, sulfate and/or methylated derivatives. Studies related to the bioavailability of almond polyphenols are also available in human population after the consumption of whole nuts or its crude extracts. In a first study, Urpi-Sarda et al. [39] analyzed and characterized the polyphenols and their metabolites present in the plasma and urine of healthy human subjects who consumed almond skin polyphenols [39]. Bioproducts of phase II and III enzymes (O-methyl glucuronide, sulfate, glucuronide and O-methyl sulfate derivatives) of naringenin, (epi)catechin and isorhamnetin were identified in plasma and urine samples in the nanomolar range, along with the glucuronide and sulfate forms of 5-(dihydroxyphenyl)- $\gamma$-valerolactone and 5-(hydroxymethoxyphenyl)- $\gamma$-valerolactone (the main bioproducts of microbial flavanols' metabolization). Moreover, several other metabolites, present in minor amounts, were found in the urine samples, always deriving from the microbial metabolization of polyphenols such as hydroxycinnamic, hydroxyphenylpropionic, hydroxybenzoic, hydroxyphenylacetic, and hydroxyhippuric acids (in their hydroxyphenylvalerolactone form). Bartolomé et al. [52], using a combination of analytical techniques (LC/ESI-MS, LC-DAD/fluorescence and MALDI-TOF-MS), identified O-methyl glucuronide, O-methyl sulfate, sulfate and glucuronide derivatives of (epi)catechin, the glucuronide conjugates of isorhamnetin and naringenin, and sulfate conjugates of isorhamnetin, together with conjugates of hydroxyphenylvalerolactones and several products of microbial metabolization products such as hydroxyphenylacetic, hydroxyphenylpropionic, hydroxyhippuric, hydroxycinnamic and hydroxybenzoic acids in plasma and urine samples. Garrido et al. [53] performed a subsequent single-blind, placebo-controlled, and randomized trial study on 16 healthy volunteers (nine men and seven women) with the aim of analyzing the changes in the urinary excretion of almond skin polyphenols and their metabolized products after different time intervals $(0-2,2-6,6-10$ and 10-24 h) from intake. The control group ingested microcrystalline cellulose, while the test group ingested $884 \mathrm{mg}$ of encapsulated flavan-3-ols, flavonols and flavanones' 
almond skin polyphenols. The maximum urinary excretion of naringenin and (epi)catechin conjugates was reached between 2 and $6 \mathrm{~h}$ after consumption, while conjugated metabolites of isorhamnetin and hydroxyphenylvalerolactones reached the maximum between 10 and $24 \mathrm{~h}$.

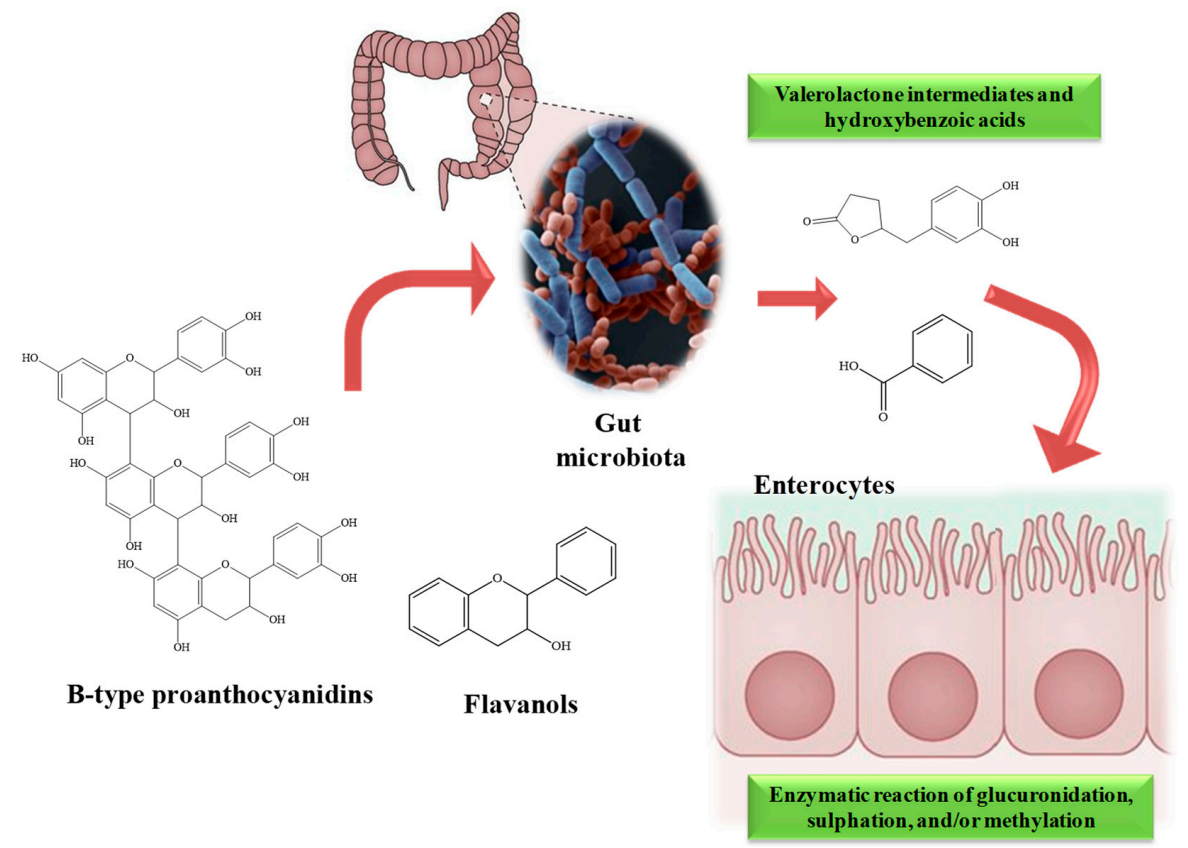

Figure 2. Schematic representation of metabolization processes of flavanols and B-type proanthocyanidins, catalyzed first by gut microbes with the formation of small phenolic compounds and inside the entherocytes by Phase I and II enzymes.

\section{Health-Promoting Properties: Evidence from Intervention Clinical Trials}

The use of almonds as a health-promoting food dates back a long time; indeed, the ancient Greeks, Persians, Chinese and Indians habitually consumed them for medical purposes in their traditions [54]. In the last 20 years, the consumption of almonds has risen significantly [55], suggesting that both in the general population and for producers the perception of these nuts has evolved from a convenient snack to an essential food for maintaining human health [56]. In a large body of studies, indeed, the consumption of almonds has been associated with various health benefits, including the modulation of serum lipid [57-60] and glucose levels [61-65], the regulation of body weight [66], and protection from several diseases, such as diabetes [67,68], obesity [69-71] and cardiovascular diseases [64,72-77]. In the present section, we summarize the most relevant evidence, derived from clinical trials carried out on humans, demonstrating the beneficial health effects of almond consumption. The studies have been grouped on the basis of their main outcomes. As shown in Table 6, the studies significantly differ in terms of population type and number, amount and source of intervention and duration. However, the most significant results are generally in agreement, providing solid evidence so physicians and nutritionists can feel confident in encouraging the use of almonds in the management of several borderline conditions. 
Table 6. Clinical trials investigating the health-promoting properties of almonds.

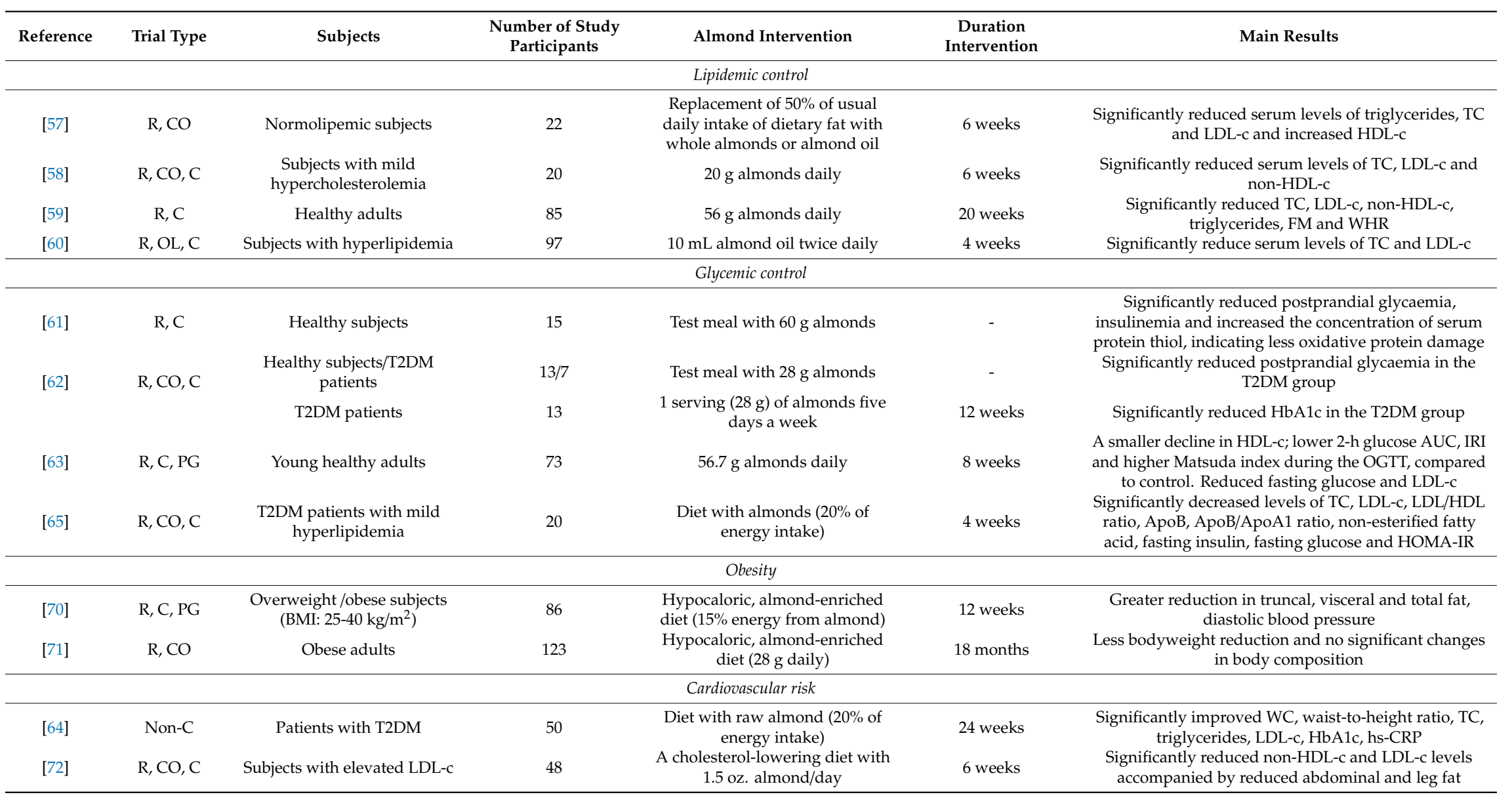


Table 6. Cont.

\begin{tabular}{|c|c|c|c|c|c|c|}
\hline Reference & Trial Type & Subjects & $\begin{array}{l}\text { Number of Study } \\
\text { Participants }\end{array}$ & Almond Intervention & $\begin{array}{c}\text { Duration } \\
\text { Intervention }\end{array}$ & Main Results \\
\hline [73] & $\mathrm{R}, \mathrm{CO}, \mathrm{C}$ & Patients with $\mathrm{CAD}$ & 45 & Diet with $85 \mathrm{~g}$ almonds daily & 6 weeks & $\begin{array}{c}\text { Unchanged vascular outcomes (vascular function, } \\
\text { peripheral arterial tonometry, pulse wave velocity), } \\
\text { serum parameters (lipid, CRP, TNF } \alpha \text {, E-selectin) and } \\
\text { blood pressure. Reduced VCAM1 and increased } \\
\text { urinary NO. }\end{array}$ \\
\hline [74] & Non-C & $\begin{array}{l}\text { Healthy men mild } \\
\text { hyperlipidemia }\end{array}$ & 30 & $60 \mathrm{~g}$ of almonds daily & 4 weeks & Significantly decreased LDL-c, TC and ApoB100 levels \\
\hline [75] & $\mathrm{R}, \mathrm{CO}, \mathrm{C}$ & Hyperlipidemic subjects & 27 & $\begin{array}{l}\text { Isoenergetic supplements: } \\
\text { full-dose almonds (73 g daily), } \\
\text { half-dose almonds+half-dose } \\
\text { muffins }\end{array}$ & 4 weeks & $\begin{array}{l}\text { Significantly reduced levels of LDL-c, LDL-c/HDL-c } \\
\text { ratio, lipoprotein A and ox-LDL }\end{array}$ \\
\hline [76] & $\mathrm{R}, \mathrm{CO}, \mathrm{C}$ & Hyperlipidemic subjects & 27 & $\begin{array}{c}\text { Isoenergetic supplements: } \\
\text { full-dose almonds ( } 73 \text { g daily), } \\
\text { half-dose almonds+half-dose } \\
\text { muffins }\end{array}$ & 4 weeks & $\begin{array}{l}\text { Increased content of OA and MUFA in TAG and NEFA } \\
\text { fractions, which are inversely associated with both } \\
\text { Framingham 10-year CHD risk score and CHD } \\
\text { lipid risk }\end{array}$ \\
\hline [77] & R, PG & Adults with prediabetes & 65 & $\begin{array}{l}\text { ADA diet containing } 20 \% \text { of } \\
\text { energy from almonds }\end{array}$ & 16 weeks & $\begin{array}{c}\text { Significantly reduced levels of insulin, HOMA-IR, } \\
\text { HOMA- } \beta, \text { LDL-c }\end{array}$ \\
\hline \multicolumn{7}{|c|}{ Inflammation } \\
\hline [78] & $\mathrm{R}, \mathrm{CO}, \mathrm{C}$ & Healthy adults & 25 & $\begin{array}{l}\text { Low-almond diet }(10 \% \\
\text { isoenergetic replacement with } \\
\text { almond) and high-almond diet } \\
\text { (20\% isoenergetic replacement } \\
\text { with almonds) }\end{array}$ & 4 weeks & $\begin{array}{l}\text { Significantly reduced levels of E-selectin in } \\
\text { high-almond diet and significantly reduced levels of } \\
\text { CRP in both diets }\end{array}$ \\
\hline \multicolumn{7}{|c|}{ Oxidative stress } \\
\hline [79] & $\mathrm{R}, \mathrm{C}$ & $\begin{array}{l}\text { Healthy subjects, } \\
\text { regular smokers }\end{array}$ & 30 & $86 \mathrm{~g}$ and $164 \mathrm{~g}$ almonds daily & 4 weeks & $\begin{array}{l}\text { Significantly reduced levels of 8-OH-dG, MDA and } \\
\text { single-strand DNA breaks. No significant effects on } \\
\text { SOD and GSH-Px. }\end{array}$ \\
\hline [80] & $\mathrm{R}, \mathrm{CO}, \mathrm{C}$ & $\begin{array}{l}\text { Healthy subjects, } \\
\text { regular smokers }\end{array}$ & 60 & $84 \mathrm{~g}$ almonds daily & 4 weeks & $\begin{array}{l}\text { Significantly increased levels of SOD and GSH-Px and } \\
\text { reduced levels of 8-OH-dG, MDA and DNA } \\
\text { strand breaks }\end{array}$ \\
\hline \multicolumn{7}{|c|}{ Serum uric acid } \\
\hline [81] & $\mathrm{R}, \mathrm{C}$ & CAD patients & 150 & $10 \mathrm{~g}$ almonds & 12 weeks & Significant reduced uric acid serum levels \\
\hline
\end{tabular}

Abbreviations: 8-OH-dG, 8-hydroxy2'-deoxyguanosine; ADA, American Diabetes Association; ApoB100, apolipoprotein B100; AUC, area under the curve; BMI, body mass index; C, controlled; CAD, coronary artery disease; CO, crossover; CRP, C-reactive protein; FM, fat mass; GSH-Px, glutathione peroxidase; HbA1c, glycosylated hemoglobin; HDL-c, high-density lipoprotein cholesterol; HOMA-IR, homeostatic model analysis for insulin resistance; HOMA- $\beta$, homeostatic model analysis for beta-cell function; hs-CRP, high-sensitivity C-reactive lipoprotein cholesterol; HOMA-IR, homeostatic model analysis for insulin resistance; HOMA- $\beta$, homeostatic model analysis for beta-cell function; hs-CRP, high-sensitivity C-reactive
protein; IRI, insulin resistance index; LDL-c, low-density lipoprotein cholesterol; MDA, malondialdehyde; MUFA, monounsaturated fatty acid; NEFA, non-esterified fatty acid; NO, nitric protein; IRI, insulin resistance index; LDL-c, low-density lipoprotein cholesterol; MDA, malondialdehyde; MUFA, monounsaturated fatty acid; NEFA, non-esterified fatty acid; NO, nitric
oxide; non-C; non-controlled; OA, oleic acid; OGTT, oral glucose tolerance test; OL, open-label; oxLDL, oxidized LDL; PG, parallel-group; R, randomized; SOD, superoxide dismutase; T2DM, type 2 diabetes mellitus; TAG, triacylglycerides; TC, total cholesterol; TC, total cholesterol; TNF $\alpha$, tumor necrosis factor- $\alpha$; VCAM1, vascular cell adhesion molecule-1; WC, waist circumference; WHR, waist-to-hip ratio. 


\subsection{Lipidemic Control}

One of the predominant beneficial effects of regular almond consumption is the control of blood lipid levels. A randomized controlled trial meta-analysis reported the association between almond consumption and the reduction of both total cholesterol (TC) and LDL-c; however, no significant effects have been observed in terms of high-density lipoprotein cholesterol (HDL-c), triglycerides (TG) or LDL-c/HDL-c ratio [82]. Similar results were provided by a study demonstrating that, in subjects with mild hypercholesterolemia, supplementation with $20 \mathrm{~g}$ almonds daily for six weeks significantly improved the lipid profile. In particular, a reduction in TC $(-8.1 \pm 2.4 \%, p=0.007)$, LDL-c $(-9.4 \pm 2.4 \%, p=0.005)$ and non-HDL-c $(-8.1 \pm 3.0 \%, p=0.013)$ serum levels was observed, compared to the placebo (corn starch capsules); however, the results for HDL-c and TG were not significant $(-4.7 \pm 2.3 \%, p=0.06$ and $-10.4 \pm 7.0 \%, p=0.08$, respectively) [58]. Similar results have been reported for hyperlipidemic subjects supplemented with $10 \mathrm{~mL}$ almond oil twice daily for four weeks, demonstrating a significant reduction in TC (from $224.95 \pm 33.59$ to $208.69 \pm 28.89 \mathrm{mg} / \mathrm{dL}, p=0.001$ ) and LDL-c serum levels (from $138.76 \pm 20.60$ to $131.05 \pm 17.89 \mathrm{mg} / \mathrm{dL}$ ). Furthermore, no statistically significant effects have been observed on TG and HDL-c [60]. However, in addition to reduction of TC and LDL-c levels, improvements in TG and HDL-c levels after almond supplementation have been observed in normolipidemic subjects [57]. Twenty-two (22) healthy men and women were randomized into two intervention groups consisting of supplementation with whole almonds or almond oil; supplementation replaced $50 \%$ of the usual daily intake of dietary fat and was followed for six weeks. After the treatment period, researchers observed significantly reduced levels of TC, TG and LDL-c and increased HDL-c in both intervention groups compared to the baseline values $(p<0.05$ for all parameters) [57], suggesting that almonds are useful for ameliorating the lipid profile, independently of the dietary source. According to the authors, the TG-lowering and HDL-c-increasing effects of almond supplementation might be due, at least in part, to their peculiar composition, characterized by high levels of unsaturated fatty acids, including MUFA and PUFA, whose effects in terms of ameliorating lipid profile are well established. Various authors agree on the beneficial role of the almond lipid fraction, which, in addition to other components, such as sterols and flavonoids, may be considered the main factor explaining the lipid-lowering effect of almonds [83]. Moreover, the authors also speculated further mechanisms involving improvements in both body weight and body composition. Although some studies did not demonstrate significant changes in body composition after supplementation with almonds (as will be discussed below), in healthy subjects long-term supplementation (20 weeks) with $56 \mathrm{~g}$ almonds daily resulted in improvements to the lipid profile (reductions in TC, LDL-c, non-HDL-c and TG serum levels) and decreased fat mass and waist-to-hip ratio [59], suggesting that, at least in this class of subjects, nut consumption may positively affect the body's fat storage, pointing to a further possible mechanism of the lipid-ameliorating effect.

\subsection{Glycemic Control}

In addition to lipidemic control, various studies focused on the role of almond supplementation in modulating glucose homeostasis [61-75]. As shown in Table 6, the studies are rather different in terms of their study populations, intervention, duration and outcomes. Indeed, interventions have been carried out on healthy subjects $[61,63]$, diabetics $[64,65]$ or both [62]. Furthermore, two studies investigated the acute effect of almond ingestion on postprandial glucose homeostasis, using standardized test meals [61,62]. In 2006, Jenkins and colleagues [61] demonstrated the effect of a meal containing almonds on glucose and insulin response and oxidative stress. Fifteen (15) $12 \mathrm{~h}$-fasting healthy subjects followed five different sessions consisting of four different meals: white bread (as the control, on two occasions), $60 \mathrm{~g}$ almonds with white bread, parboiled rice and mashed potatoes. Each meal contained $50 \mathrm{~g}$ of carbohydrates and was balanced for fat and protein (except for the white bread). The protocol was planned with a one-week wash-out period between each session. Among the main results, the authors observed that the almond-containing meal positively affected satiety (the incremental response area was greater than the control after $2 \mathrm{~h}$ and $4 \mathrm{~h}, p=0.047$ and 0.011 , respectively), postprandial glycaemia 
(peak heights: almonds $=106 \pm 4 \mathrm{mg} / \mathrm{dL}$, rice $=104 \pm 2 \mathrm{mg} / \mathrm{dL}$, potatoes $=119 \pm 4 \mathrm{mg} / \mathrm{dL}$, bread $=124 \pm 4$; $p<0.001$ for all), insulinemia (peak heights: almonds $=32.25 \pm 3.45 \mu \mathrm{IU} / \mathrm{mL}$, rice $=32.42 \pm 4.03 \mu \mathrm{IU} / \mathrm{mL}$, potatoes $=55.87 \pm 4.32 \mu \mathrm{IU} / \mathrm{mL}$, bread $=46.22 \pm 5.18 \mu \mathrm{IU} / \mathrm{mL} ; p<0.001$ almonds vs. potato and $\leq 0.042$ almonds vs. bread) and oxidative stress, assessed through an evaluation of protein thiol concentrations (changes in serum protein thiol concentrations: almonds $=15 \pm 14 \mathrm{mmol} / \mathrm{L}$, combination of data from the other three meals $=-10 \pm 8 \mathrm{mmol} / \mathrm{L} ; p=0.021$ ) [61]. Overall, these data suggest that the addition of almonds to a meal significantly improves both the glycemic and insulinemic control (decreasing the meal glycemic index, probably due to their fat, protein and fiber content) and reduces oxidative stress-induced protein damage, which commonly occurs as a consequence of the prolonged hyperglycemia; this last effect may also be due to the high content of antioxidant compounds, mainly polyphenols. A similar study was conducted by Cohen and Johnston [62] investigating the effect of almond consumption during a meal in both healthy subjects and patients with type 2 diabetes mellitus (T2DM). Study participants were randomized into two groups, consuming a standardized meal with or without almonds ( $28 \mathrm{~g}$ ). Both meals were isocaloric, with equal amounts of carbohydrates and fats. After a one-week wash-out period, subjects in one group moved to the other, following a crossover study design. Interestingly, researchers observed that almond consumption significantly reduced the postprandial glycaemia only in T2DM subjects $(-30 \%, p=0.043)$; on the other hand, serum levels of insulin and glucagon-like peptide-1 (GLP-1) were not significantly impacted in either group. In the same study, the authors also carried out a small chronic study on T2DM patients randomized into two groups: almond supplementation (1 oz.) and cheese (two sticks); both intervention groups consumed this diet five days per week for 12 weeks. After the intervention period, significantly reduced levels of glycosylated hemoglobin $(\mathrm{HbA} 1 \mathrm{c})$ were found in the almond group [62]. According to the authors, the observed hypoglycemic effect of almonds might be due to the slowing of gastric emptying (as a consequence of the fat and protein contained in the nuts), but also to the presence of polyphenols, mainly flavonoids, that help control glucose blood levels [62,84], inhibiting amylase [62]. Interestingly, flavonoids are effective ay inhibiting the activity of salivary amylase, which represents a remarkable target for glycemic control in diabetics since in this class of patients the activity of pancreatic amylase is strongly reduced (28\% to $35 \%$ ) $[85,86]$. Further studies investigated the effect of almond consumption in chronic diseases. It has been demonstrated that in healthy adults eight-week supplementation with $56.7 \mathrm{~g}$ almonds significantly reduced fasting glucose, although, similarly to the study of Cohen and Johnston [62], insulin and glucagon-like peptide 1 (GLP-1) levels were not impacted; however, researchers observed increased sensitivity to insulin, evaluated by both the insulin resistance index and the Matsuda index as 34\% lower and 82\% higher, respectively, than the control [63]. In T2DM patients, long-term supplementation with almonds (four and 24 weeks) resulted in significantly reduced $\mathrm{HbA} 1 \mathrm{c}$ (from $7.7 \pm 1.2$ to $7.3 \pm 1.1 \%, p=0.04)$ [47], fasting glucose $(4.1 \%, p=0.023)$, fasting insulin $(0.8 \%$, $p=0.018)$ and homeostatic model analysis for insulin resistance (HOMA-IR) $(9.2 \%, p=0.004)$ [65].

\subsection{Obesity}

The two studies reported in Table 6, demonstrating the role of almond consumption in overweight [70] and obese subjects [70,71], present quite different results. A 12-week clinical trial was carried out with 86 healthy subjects with a body mass index (BMI) that ranged from 25 to $40 \mathrm{~kg} / \mathrm{m}^{2}$ (thus classified as overweight or obese), who were randomized into two diet intervention groups: an almond-enriched hypocaloric diet (AED, 15\% of total kcal from almonds) and a nut-free hypocaloric diet (NFD). Each diet provided a daily 500-kcal deficit, with the energy requirement estimated by predictive equations. After the intervention period, although subjects in both groups lost body weight, in those that followed the AED significantly higher reductions in total and truncal fat mass were observed, as well as an increase in the total and truncal fat-free mass $(p<0.05)$. According to the authors, these results might be mainly due to the high UFA content in almonds, which have high fat oxidation rates that contribute to reducing visceral fat [70]. In 2012, Foster and co-workers [71] conducted a very long-term diet intervention trial (18 months) on obese subjects (baseline BMI: $34.0 \pm 3.6 \mathrm{~kg} / \mathrm{m}^{2}$ ), randomized 
into AED (28 g almonds daily) or NFD diet intervention groups. Although there were positive results after the 18-month intervention period, the researchers observed no statistically significant differences between the two groups in terms of weight loss, body composition or blood pressure; however, significantly decreased levels of TG and TC were observed in the AED group at six months but not at the end of the study [71].

\subsection{Cardiovascular Risk}

The role of impaired glucose and/or lipid homeostasis and obesity in contributing to cardiovascular risk has been well established, either as single or combined risk factors. It appears clear, therefore, that therapeutic strategies, as well as dietary approaches aimed to counteract these metabolic alterations, result in reduced cardiovascular risk. According to the aforementioned evidence, this might be enough to recommend the regular consumption of almonds to achieve a reduction in cardiovascular risk in susceptible subjects. However, various studies directly investigated the role of almond consumption in various factors related to cardiovascular diseases, including the glucose and lipid profile [64,72-77], body fat [64,72], inflammation-related markers [64,73] and vascular outcomes [73]. However, the reported studies have differences in terms of population, intervention, duration and results, providing no weighted evidence for a general conclusion on the positive role of almond consumption in the management of cardiovascular diseases. In general, as reported in Table 6, all the studies demonstrate significant improvements in (i) blood lipids, in terms of reduced levels of TC, TG [64,74], LDL-c [64,72,75,77], non-HDL-c [72], ApoB 100 [64], lipoprotein A, oxidized LDL-c [75]; (ii) glucose homeostasis, in terms of reduced $\mathrm{HbA1c}$ [64], insulin, HOMA-IR and HOMA for beta-cell function (HOMA- $\beta$ ) [77]; (iii) body composition, in terms of reduced waist circumference, waist-to-height ratio [64] and abdominal and leg fat [72]; and (iv) inflammatory status [64].

In 2015, Chen and colleagues [73] conducted a study on 45 patients with coronary artery disease following a six-week diet with $85 \mathrm{~g}$ almonds daily. After the intervention period, the researchers observed no significant improvements in vascular outcomes, evaluated by measuring the flow-mediated dilation, one of the most accredited techniques for monitoring the endothelial function; similarly, no significant improvements were observed in serum parameters, including lipids, $C$ reactive protein (CRP), tumor-necrosis factor (TNF)- $\alpha$ and E-selectin. However, they demonstrated a slightly significant reduction of vascular cell adhesion molecule- $1(-5.3 \%, p=0.064)$ and a nonsignificant increase in urinary nitric oxide $(+17.5 \%, p=0.112)$, suggesting that almonds might modestly contribute to improving the endothelial function [73]. Interestingly, two randomized, crossover studies from the same authors directly investigated the effect of almond consumption on the risk of coronary heart disease (CHD) using the Framingham's 10-year risk score [75,76]. Both studies were carried out on 27 hyperlipidemic men and postmenopausal women randomized into three one-month diet intervention groups: control (muffin, $147 \pm 6 \mathrm{~g} /$ day), full-dose almonds ( $73 \pm 3 \mathrm{~g} /$ day) and half-dose almonds ( $37 \pm 2 \mathrm{~g} /$ die) + half-dose muffin $(75 \pm 3 \mathrm{~g} /$ day); during the intervention period, all subjects were instructed to follow their noncontrolled low-fat diet. After the intervention period, significant improvements in lipid profile were observed in both the almond intervention groups, following a dose-dependent manner $[75,76]$; in particular, it was estimated that every $\sim 7 \mathrm{~g}$ almonds daily are able to reduce LDL-c by $\sim 1 \%$, resulting in a $2 \%$ reduction of CHD risk (CHD risk: $-9.2 \pm 3.5 \%, p=0.015$, full-dose almond group) [75]. Notably, an association was observed between the consumption of almonds and the reduction of the Framingham 10-year CHD risk score $(R=-0.247, p=0.026)$, which translates into a $3.5 \%$ reduction of CHD risk for every $30 \mathrm{~g}$ increase in almond intake [76]. Nevertheless, although they should be interpreted with caution, the data presented herein might allow for considering almonds as a useful dietary approach in the long-term prevention of cardiovascular risk.

\subsection{Inflammation and Oxidative Stress}

The anti-inflammatory potential of almond consumption has been investigated through a randomized, crossover study [78] involving 25 healthy subjects, randomized into three-four week 
diet interventions: control cholesterol-lowering nut-free diet, low-almond diet (10\% of total energy) and high-almond diet (20\% of total energy). After the intervention period, E-selectin levels were significantly lower in the high-almond group compared to the placebo $(-7.8 \%)$; interestingly, it was estimated that for every $1 \%$ increase in energy replaced with almonds, E-selectin decreased by $0.18 \mu \mathrm{g} / \mathrm{L}$. On the other hand, both of the almond diets significantly reduced serum levels of C-reactive protein (CRP). According to the authors, the anti-inflammatory effects might be mainly attributed to the high MUFA content, which has been considered responsible for the decreased levels of E-selectin and CRP. Additionally, further almond components, including magnesium, arginine and phytochemicals, may also contribute to reducing the levels of inflammatory mediators [78]. The antioxidant activity of almonds has been evaluated in two studies on habitual smokers [79,80]. A pilot study was conducted on 30 young subjects habitual smoking 10-20 cigarettes daily, and with at least a five-year smoking history. Subjects were randomized into three groups ( $n=10$ per group): control (no almonds), $84 \mathrm{~g}$ and $168 \mathrm{~g}$ almond supplementation daily for four weeks. After the treatment period, the percentage of tail DNA was reduced in both the almond-supplemented groups, with statistically significant differences in the higher-dose group ( $p<0.05$ compared to the control group); in addition, in both the almond-supplemented groups significantly reduced levels of 8-hydroxy-2'-deoxyguanosine (8-OH-dG) and malondialdehyde (MDA) ( $p<0.05$ for all, compared to the control group) were found. However, no significant effects were observed for superoxide dismutase (SOD) and glutathione peroxidase (GSH-Px) [79]. Subsequently, the same researchers, starting from these preliminary results, carried out another similar study on a larger cohort with the same inclusion criteria. Also, in this case, after the intervention period, DNA damage, MDA and 8-OH-dG were significantly reduced (23\%, 34\% and $28 \%$, respectively); however, significantly increased levels of SOD and GSH-Px were also observed. According to the authors, this discrepancy of the results from the pilot study can be explained by the higher sample size in the subsequent study [80]. As the authors claimed, these beneficial effects should be attributed to the high content of antioxidant compounds in almonds, mainly present in the skin [79]. Overall, these results suggest that almond consumption may contribute to protection against oxidative stress and related consequences among smokers.

\subsection{Serum Uric Acid}

A large, randomized, nut-free diet-controlled study demonstrated the uricemia-lowering effect of 12 weeks of regular consumption of almonds ( $10 \mathrm{~g}$ daily) in 150 coronary artery disease patients. After the intervention period, at week 6 and week 12 significantly reduced serum levels of uric acid were registered in both men $(-15 \%$ and $-17 \%$, respectively; $p<0.05$ for all, compared to nut-free diet group) and women $(-12 \%$ and $-16 \%$, respectively; $p<0.05$ for all, compared to nut-free diet group) [81].

\subsection{Secondary Metabolites of Almonds as a Functional Food and Prebiotics}

Several secondary metabolites have been identified in almonds, mainly represented by the polyphenols found in the skin. Although the polyphenol amount and antioxidant activity of almonds from California is a function of the cultivar and the harvest year [30], the mean and $25 \%$ to $75 \%$ percentile contents reported in the literature were (per $100 \mathrm{~g}$ almonds): $162 \mathrm{mg}$ (67.1 to $257 \mathrm{mg}$ ) proanthocyanins, $82.1 \mathrm{mg}$ (72.9 to $91.5 \mathrm{mg}$ ) hydrolysable tannins, $61.2 \mathrm{mg}$ (13.0 to $93.8 \mathrm{mg}$ ) flavonoids (non-isoflavone), $5.5 \mathrm{mg}$ (5.2 to $12 \mathrm{mg}$ ) aldehydes and phenolic acids, and $0.7 \mathrm{mg}$ (0.5 to $0.9 \mathrm{mg}$ ) stilbenes, isoflavones, and lignans [31]. The extraction of the seed with solvent releases additional phenolic acids, proanthocyanins and phenols. The influence of roasting, pasteurization and storage on the almond skins' polyphenol content has been widely investigated: Bolling et al. [32] reported that roasting led to a decrease in total phenols and ferric reducing antioxidant power but did not affect the amounts of flavonoids and phenolic acids. On the contrary, Garrido et al. [87] found that roasted almonds had the highest antioxidant activity in terms of ORAC values. It is well known that industrial blanching for the removal of the skin consistently reduces almonds' polyphenol content, since most of the water-soluble compounds end up in the water and the blanched skin $[44,88]$. A recent 
study has demonstrated that polyphenols in almond skins after blanching were able to modulate plasma biomarkers of oxidative stress, including glutathione status, glutathione peroxidase activity and resistance of LDL to oxidation in healthy humans [89]. The polyphenols retained in the blanched water, which is currently considered a byproduct of the almond processing industry, could be further utilized for their antimicrobial and antiviral properties [90,91]. There are just a few scientific works that have analyzed the contribution of polyphenols to the health-promoting activity of almonds; the first preclinical studies of polyphenol-rich almond skin or almond extracts, for instance, showed the direct involvement of these components in biological activities such as antiviral activity, antioxidant, detoxicant, anti-inflammatory, anti-platelet aggregation activities and UV protection [31,92]. Therefore, almond skins have a unique polyphenol profile contributing to both food quality and health-promoting functions. The possibility of using almond bioactives as additives in food could be explored: the need for natural food additives as a replacement of synthetic compounds has notably increased over the last decade [92]. Almond polyphenols have antioxidant, antimicrobial and antiviral properties, appealing as a natural food preservative. For example, the addition of almond skin in powder form reduced lipid oxidation in raw chicken breasts under refrigeration and freezing conditions [93]. Almond skin powder also reduced oxidation and increased the shelf life of ground beef [94] and can be used as a preservative in products containing nuts [95]. Further development and optimization could promote the use of almond skin polyphenols in the food industry. A number of studies have indicated that the consumption of almonds and almond skins may lead to an improvement in the intestinal microbiota composition, inducing the growth and/or activity of beneficial bacteria [96-98]. In one study performed by Mandalari et al. [16], finely ground almonds and defatted finely ground almonds were utilized in a combined model of the gastrointestinal tract (in vitro gastric and duodenal digestion), followed by microbial metabolization of the resulting fractions to analyze their influences and activities on the composition and metabolic potential of gut bacteria populations. Finely ground almonds significantly stimulate the growth of bifidobacteria and Eubacterium rectale populations, whereas there were no significant differences in response to defatted finely ground almonds. Liu et al. [96] have analyzed the prebiotic effects, on healthy humans, of almond and almond skin intake. The analysis of fecal samples over six weeks after intervention showed a significant increase in Bifidobacterium spp. and Lactobacillus spp. populations, whereas Escherichia coli remained stable and Clostridum perfringens growth was significantly repressed. The gut microbiota composition was analyzed after the consumption of almonds ( $0,1.5$ or 3 servings/day for 18 days): no increase in lactobacilli and bifidobacteria was detected [97]. In a four-week animal trial, consumption of raw and roasted almonds led to an increase of Bifidobacterium spp. and Lactobacillus spp. numbers, decreasing the growth of Enterococcus spp. [14]. Raw almonds led to an increase in bifidobacteria numbers, associated with higher $\beta$-galactosidase activity and lower $\beta$-glucuronidase and azoreductase activity compared with roasted almonds. Fiber and other components in almonds and almond skins have potential prebiotic properties. Mandalari et al. [98] investigated the prebiotic effect of natural (NS) and blanched (BS) almond skins in vitro. Both NS and BS significantly increased the bifidobacteria and Clostridium coccoides/Eubacterium rectale numbers. This study demonstrated that the presence of polyphenols in almond skins did not affect bacterial fermentation, and that almond skins, which are by-products of industrial blanching, could potentially be used as prebiotics.

\section{Conclusions}

In the present review, we have discussed the nutritional value, biological activities and phytochemical profile of almonds, a popular and important medicinal and dietary nut with a long history of use. The kernels are rich in fat (MUFA and PUFA), carbohydrates (fiber, etc.), proteins, vitamins (vitamin E, vitamin B, etc.), minerals (copper, calcium, magnesium, etc.) and diverse bioactive compounds (phytosterols, polyphenols, etc.) and are used as a natural antioxidant and anti-inflammatory. The abundant micronutrient polyphenols play an important role in protection from chronic degenerative diseases. Indeed, frequent consumption of almonds has been associated with 
reduced risk of various diseases, including obesity, hypertension, diabetes mellitus and metabolic syndrome, owing to their LDL-c reducing ability. These activities were attributed to the lipid fraction and polyphenolic compounds of almonds. However, the health benefits of these components depend on their bioavailability and ingested amount. It was also reported that the consumption of almonds and their skin may improve the intestinal microbiota profile and lead to health benefits. A lot of evidence suggests the health-promoting properties of almonds, though several aspects remain unrevealed, since the influence of microstructural components on the release of phytonutrients from this complex matrix and the potential of bioactive compounds to activate intracellular signal cascade and modulate complex processes inside the organism are still poorly understood.

Author Contributions: Conceptualization, D.B. and G.M.; writing-original draft preparation, D.B., S.M.N., A.S., M.R., R.R., A.S.S., G.A., A.A., G.C.T., İ.S. and G.M.; writing-review and editing, D.B., S.M.N., A.S., M.R., R.R., A.S.S., G.A., A.A., G.C.T., İ.S. and G.M.; supervision, D.B. and G.M.; project administration, D.B. and G.M. All authors have read and agreed to the published version of the manuscript.

Funding: Davide Barreca and Giuseppina Mandalari were supported by FFABR 2017 grants (ANVUR/MIUR, Italian Ministry of University and Research). Antoni Sureda was supported by the Instituto de Salud Carlos III (CIBEROBN CB12/03/30038), which is co-funded by the European Regional Development Fund.

Conflicts of Interest: The authors declare no conflict of interest.

\section{Abbreviations}

$\begin{array}{ll}\text { AED } & \text { almond-enriched hypocaloric diet; } \\ \text { BMI } & \text { body mass index; } \\ \text { CHD } & \text { coronary heart disease; } \\ \text { CRP } & \text { C reactive protein; } \\ \text { GLP-1 } & \text { glucagon-like peptide-1; } \\ \text { HbA1c } & \text { glycosylated hemoglobin; } \\ \text { GSH-Px } & \text { glutathione peroxidase; } \\ \text { HDL-c } & \text { high-density lipoprotein cholesterol; } \\ \text { HOMA-IR } & \text { homeostatic model analysis for insulin resistance; } \\ \text { HOMA- } \beta & \text { homeostatic model analysis for beta-cell function; } \\ \text { LDL-c } & \text { low-density lipoprotein cholesterol; } \\ \text { MDA } & \text { malondialdehyde; } \\ \text { MUFA } & \text { monounsaturated fatty acids; } \\ \text { NFD } & \text { nut-free hypocaloric diet; } \\ \text { PUFA } & \text { polyunsaturated fatty acids; } \\ \text { SOD } & \text { superoxide dismutase; } \\ \text { TC } & \text { total cholesterol; } \\ \text { TG } & \text { triglycerides; } \\ \text { TNF } & \text { tumor-necrosis factor; } \\ \text { T2DM } & \text { type 2 diabetes mellitus; } \\ \text { 8-OH-dG } & \text { 8-hydroxy-2'-deoxyguanosine. } \\ & \end{array}$

\section{References}

1. Casas-Agustench, P.; Salas-Huetos, A.; Salas-Salvadó, J. Mediterranean nuts: Origins, ancient medicinal benefits and symbolism. Public Health Nutr. 2011, 14, 2296-2301. [CrossRef]

2. Becerra-Tomás, N.; Paz-Graniel, I.W.C.; Kendall, C.; Kahleova, H.; Rahelić, D.; Sievenpiper, J.L.; Salas-Salvadó, J. Nut consumption and incidence of cardiovascular diseases and cardiovascular disease mortality: A meta-analysis of prospective cohort studies. Nutr. Rev. 2019, 77, 691-709. [CrossRef] [PubMed]

3. de Souza, R.G.M.; Schincaglia, R.M.; Pimentel, G.D.; Mota, J.F. Nuts and Human Health Outcomes: A Systematic Review. Nutrients 2017, 9, 1311. [CrossRef] [PubMed]

4. Bechthold, A.; Boeing, H.; Schwedhelm, C.; Hoffmann, G.; Knüppel, S.; Iqbal, K.; Schwingshackl, L. Food groups and risk of coronary heart disease, stroke and heart failure: A systematic review and dose response meta-analysis of prospective studies. Crit. Rev. Food Sci. Nutr. 2017, 59, 1071-1090. [CrossRef] [PubMed] 
5. Aune, D.; Keum, N.; Giovannucci, E.; Fadnes, L.T.; Boffetta, P.; Greenwood, D.C.; Norat, T. Nut consumption and risk of cardiovascular disease, total cancer, all-cause and cause-specific mortality: A systematic review and dose-response meta-analysis of prospective studies. BMC Med. 2016, 14, 207. [CrossRef] [PubMed]

6. Blanco Mejia, S.; Kendall, C.W.; Viguiliouk, E.; Augustin, L.S.; Ha, V.; Cozma, A.I.; Mirrahimi, A.; Maroleanu, A.; Chiavaroli, L.; Leiter, L.A.; et al. Effect of Tree Nuts on Metabolic Syndrome Criteria: A Systematic Review and Meta-analysis of Randomised Controlled Trials. BMJ Open 2014, 4, e004660. [CrossRef] [PubMed]

7. Rajaram, S.; Sabaté, J. Nuts, body weight and insulin resistance. Br. J. Nutr. 2006, 96, S79-S86. [CrossRef]

8. Gradziel, T.M. Almond (Prunus dulcis) breeding. In Breeding Plantation Tree Crops: Temperate Species; Jain, S.M., Priyadarshan, P.M., Eds.; Springer: New York, NY, USA, 2009; pp. 1-31, ISBN 9780387712031.

9. Oliveira, I.; Meyer, A.S.; Afonso, S.; Aires, A.; Goufo, P.; Trindade, H.; Gonçalves, B. Phenolic and fatty acid profiles, $\alpha$-tocopherol and sucrose contents, and antioxidant capacities of understudied Portuguese almond cultivars. J. Food Biochem. 2019, 43, e12887. [CrossRef]

10. Barreira, J.C.; Casal, S.; Ferreira, I.C.; Peres, A.M.; Pereira, J.A.; Oliveira, M.B. Supervised chemical pattern recognition in almond (Prunus dulcis) Portuguese PDO cultivars: PCA- and LDA-based triennial study. J. Agric. Food Chem. 2012, 60, 9697-9704. [CrossRef]

11. Yada, S.; Lapsley, K.; Huang, G. A review of composition studies of cultivated almonds: Macronutrients and micronutrients. J. Food Compos. Anal. 2011, 24, 469-480. [CrossRef]

12. Alamprese, C.; Ratti, S.; Rossi, M. Effects of roasting conditions on hazelnut characteristics in a two-step process. J. Food Eng. 2009, 95, 272-279. [CrossRef]

13. Amaral, J.S.; Casal, S.; Seabra, R.M.; Oliveira, B.P. Effects of roasting on hazelnut lipids. J. Agric. Food Chem. 2006, 54, 1315-1321. [CrossRef] [PubMed]

14. Liu, Z.; Wang, W.; Huang, G.; Zhang, W.; Ni, L. In vitro and in vivo evaluation of the prebiotic effect of raw and roasted almonds (Prunus amygdalus). J. Sci. Food Agric. 2016, 96, 1836-1843. [CrossRef] [PubMed]

15. Mandalari, G.; Nueno-Palop, C.; Bisignano, G.; Wickham, M.S.; Narbad, A. Potential prebiotic properties of almond (Amygdalus communis L.) seeds. Appl. Environ. Microbiol. 2008, 74, 4264-4270. [CrossRef]

16. Chen, C.-Y.; Lapsley, K.; Blumberg, J. A nutrition and health perspective on almonds. J. Sci. Agric. Food Sci. 2006, 86, 2245-2250. [CrossRef]

17. Yada, S.; Huang, G.; Lapsley, K. Natural variability in the nutrient composition of california-grown almonds. J. Food Compos. Anal. 2013, 30, 80-85. [CrossRef]

18. Gama, T.; Wallace, H.M.; Trueman, S.J.; Bai, S.H. Variability in crude protein and mineral nutrient concentrations of almonds. Acta Hortic. 2018, 1219, 259-264. [CrossRef]

19. U.S. Department of Agriculture, A.R.S. U.S. Department of Agriculture, Agricultural Research Service. FoodData Central. 2019. Available online: https://fdc.nal.usda.gov/ (accessed on 1 March 2020).

20. Tabela de Composição de Alimentos (TCA). Instituto Nacional de Saúde Doutor Ricardo Jorge, Lisboa, Version 3.2-2018. Available online: http://portfir.insa.pt/foodcomp/search (accessed on 4 October 2019).

21. Pennington, J.A.T. Applications of food composition data: Data sources and considerations for use. J. Food Compos. Anal. 2008, 21, S3-S12. [CrossRef]

22. Piscopo, A.; Romeo, F.V.; Petrovicova, B.; Poiana, M. Effect of the harvest time on kernel quality of several almond varieties (Prunus dulcis (Mill.) D.A. Webb). Sci. Hortic. 2010, 125, 41-46. [CrossRef]

23. Kazantzis, I.; Nanos, G.D.; Stavroulakis, G.G. Effect of harvest time and storage conditions on almond kernel oil and sugar composition. J. Sci. Food Agric. 2003, 83, 354-359. [CrossRef]

24. Summo, C.; Palasciano, M.; Angelis, D.D.; Paradiso, V.M.; Caponio, F.; Pasqualone, A. Evaluation of the chemical and nutritional characteristics of almonds (Prunus dulcis (Mill). D.A. Webb) as influenced by harvest time and cultivar. J. Sci. Food Agric. 2018, 98, 5647-5655. [CrossRef] [PubMed]

25. Ahrens, S.; Venkatachalam, M.; Mistry, A.M.; Lapsley, K.; Sathe, S.K. Almond (Prunis dulcis L.) protein quality. Plant Foods Hum. Nutr. 2005, 60, 123-128. [CrossRef] [PubMed]

26. Muhammad, S.; Sanden, B.L.; Lampinen, B.D.; Saa, S.; Siddiqui, M.I.; Smart, D.R.; Olivos, A.; Shackel, K.A.; DeJong, T.; Brown, P.H. Seasonal changes in nutrient content and concentrations in a mature deciduous tree species: Studies in almond (Prunus dulcis (Mill.) D. A. Webb). Eur. J. Agron. 2015, 65, 52-68. [CrossRef]

27. Barreira, J.C.M.; Pereira, J.A.; Oliveira, M.B.P.P.; Ferreira, I.C.F.R. Sugars profiles of different chestnut (Castanea sativa Mill.) and almond (Prunus dulcis) cultivars by HPLC-RI. Plant Foods Hum. Nutr. 2010, 65, 38-43. [CrossRef] [PubMed] 
28. Balta, F.; Battal, P.; Fikret Balta, M.; Yoruk, H.I. Free sugar compositions based on kernel taste in almond genotypes Prunus dulcis from Eastern Turkey. Chem. Nat. Compd. 2009, 45, 221-224. [CrossRef]

29. Gu, L.; Kelm, M.A.; Hammerstone, J.F.; Beecher, G.; Holden, J.; Haytowitz, D.; Prior, R.L. Screening of foods containing proanthocyanidins and their structural characterization using LC-MS/MS and thiolytic degradation. J. Agric. Food Chem. 2003, 51, 7513-7521. [CrossRef]

30. Bolling, B.W.; Dolnikowski, G.; Blumberg, J.B.; Chena, C.-Y.O. Polyphenol content and antioxidant activity of California almonds depend on cultivar and harvest year. Food Chem. 2010, 122, 819-825. [CrossRef]

31. Bolling, B.W. Almond Polyphenols: Methods of Analysis, Contribution to Food Quality, and Health Promotion. Compr. Rev. Food Sci. Food Saf. 2017, 16, 346-368. [CrossRef]

32. Bolling, B.W.; Blumberg, J.B.; Chen, C.O. The influence of roasting, pasteurisation, and storage on the polyphenol content and antioxidant capacity of California almond skins. Food Chem. 2010, 123, 1040-1047. [CrossRef]

33. Monagas, M.; Garrido, I.; Lebrón-Aguilar, R.; Bartolome, B.; Gómez-Cordovés, C. Almond (Prunus dulcis(Mill.) D.A. Webb) skins as a potential source of bioactive polyphenols. J. Agric. Food Chem. 2007, 55, 8498-8507. [CrossRef]

34. Pérez-Jiménez, J.; Torres, J.L. Analysis of proanthocyanidins in almond blanch water by HPLC-ESI-QqQ-MS/MS and MALDI-TOF/TOF MS. Food Res. Int. 2012, 49, 798-806. [CrossRef]

35. De Pascual-Teresa, S.; Gutierrez-Fernandez, Y.; Rivas-Gonzalo, J.C.; Santos Buelga, C. Characterization of monomeric and oligomeric flavan-3-ols from unripe almond fruits. Phytochem. Anal. 1998, 9, $21-27$. [CrossRef]

36. Monagas, M.; Garrido, I.; Lebrón-Aguilar, R.; Gómez-Cordovés, C.; Rybarczyk, A.; Amarowicz, R.; Bartolomé, B. Comparative flavan-3-ol profile and antioxidant capacity of roasted peanut, hazelnut, and almond skins. J. Agric. Food Chem. 2009, 57, 10590-10599. [CrossRef]

37. Tsujita, T.; Shintani, T.; Sato, H. Alpha-amylase inhibitory activity from nut seed skin polyphenols. 1. Purification and characterization of almond seed skin polyphenols. J. Agric. Food Chem. 2013, 61, 4570-4576. [CrossRef] [PubMed]

38. Xie, L.; Roto, A.V.; Bolling, B.W. Characterization of ellagitannins, gallotannins, and bound proanthocyanidins from California almond (Prunus dulcis) varieties. J. Agric. Food Chem. 2012, 60, 12151-12156. [CrossRef] [PubMed]

39. Urpi-Sarda, M.; Garrido, I.; Monagas, M.; Gómez-Cordovés, C.; Medina-Remón, A.; Andres-Lacueva, C.; Bartolomé, B. Profile of plasma and urine metabolites after the intake of almond [Prunus dulcis (Mill.) D.A. Webb] polyphenols in humans. J. Agric. Food Chem. 2009, 57, 10134-10142. [CrossRef] [PubMed]

40. Harnly, J.M.; Doherty, R.F.; Beecher, G.R.; Holden, J.M.; Haytowitz, D.B.; Bhagwat, S.; Gebhardt, S. Flavonoid content of U.S. fruits, vegetables, and nuts. J. Agric. Food Chem. 2006, 54, 9966-9977. [CrossRef]

41. Wijeratne, S.S.K.; Abou-Zaid, M.M.; Shahidi, F. Antioxidant polyphenols in almond and its coproducts. J. Agric. Food Chem. 2006, 54, 312-318. [CrossRef]

42. Arráez-Román, D.; Fu, S.; Sawalha, S.M.S.; Segura-Carretero, A.; Fernández-Gutiérrez, A. HPLC/CE-ESI-TOF-MS methods for the characterization of polyphenols in almond-skin extracts. Electrophoresis 2010, 31, 2289-2296. [CrossRef]

43. Takeoka, G.R.; Dao, L.T. Antioxidant constituents of almond [Prunus dulcis (Mill.) D.A. Webb] Hulls. J. Agric. Food Chem. 2003, 51, 496-501. [CrossRef]

44. Mandalari, G.; Tomaino, A.; Arcoraci, T.; Martorana, M.; LoTurco, V.; Cacciola, F.; Rich, G.T.; Bisignano, C.; Saija, A.; Dugo, P.; et al. Characterization of polyphenols, lipids and dietary fibre from almond skins (Amygdalus communis L.). J. Food Comp. Anal. 2010, 23, 166-174. [CrossRef]

45. Thompson, L.; Boucher, B.; Liu, Z.; Cotterchio, M.; Kreiger, N. Phytoestrogen content of foods consumed in Canada, including isoflavones, lignans, and coumestan. Nutr. Cancer 2006, 54, 184-201. [CrossRef] [PubMed]

46. Kuhnle, G.G.C.; Dell'Aquila, C.; Aspinall, S.M.; Runswick, S.A.; Mulligan, A.A.; Bingham, S.A. Phytoestrogen content of beverages, nuts, seeds, and oils. J. Agric. Food Chem. 2008, 56, 7311-7315. [CrossRef]

47. Bornhorst, G.M.; Roman, M.J.; Dreschler, K.C.; Singh, R.P. Physical property changes in raw and roasted almonds during gastric digestion in vivo and in vitro. Food Biophys. 2013, 9, 39-48. [CrossRef]

48. Bornhorst, G.M.; Roman, M.J.; Rutherfurd, S.M.; Burri, B.J.; Moughan, P.J.; Singh, R.P. Gastric digestion of raw and roasted almonds in vivo. J. Food Sci. 2013, 78, H1807-H1813. [CrossRef] [PubMed] 
49. Grundy, M.M.; Grassby, T.; Mandalari, G.; Waldron, K.W.; Butterworth, P.J.; Berry, S.E.; Ellis, P.R. Effect of mastication on lipid bioaccessibility of almonds in a randomized human study and its implications for digestion kinetics, metabolizable energy, and postprandial lipemia. Am. J. Clin. Nutr. 2015, 101, 25-33. [CrossRef]

50. Grundy, M.M.-L.; Wilde, P.J.; Butterworth, P.J.; Gray, R.; Ellis, P.R. Impact of cell wall encapsulation of almonds on in vitro duodenal lipolysis. Food Chem. 2015, 185, 405-412. [CrossRef]

51. Mandalari, G.; Grundy, M.M.L.; Grassby, T.; Parker, M.L.; Cross, K.L.; Chessa, S.; Butterworth, P.J. The effects of processing and mastication on almond lipid bioaccessibility using novel methods of in vitro digestion modelling and micro-structural analysis. Br. J. Nutr. 2014, 112, 1521-1529. [CrossRef]

52. Bartolomé, B.; Monagas, M.; Garrido, I.; Gómez-Cordovés, C.; Martín-Alvarez, P.J.; Lebrón-Aguilar, R.; Urpí-Sardà, M.; Llorach, R.; Andrés-Lacueva, C. Almond (Prunus dulcis (Mill.) D.A. Webb) polyphenols: From chemical characterization to targeted analysis of phenolic metabolites in humans. Arch. Biochem. Biophys. 2010, 501, 124-133. [CrossRef]

53. Garrido, M.; Urpi-Sarda, M.; Monagas, C.; Gomez-Cordoves, P.J.; Martin-Alvarez, R.; Llorach, B.; Bartolome, C.; Andres-Lacueva, C. Targeted analysis of conjugated and microbial-derived phenolic metabolites in human urine after consumption of an almond skin phenolic extract. J. Nutr. 2010, 140, 1799-1807. [CrossRef]

54. Albala, K. Almonds along the Silk Road: The exchange and adaptation of ideas from West to East. Petits Propos Culin. 2009, 88, 19-34.

55. Ryan, N.T. World almond market. In Almonds: Botany, Production and Uses; Socias i Company, R., Gradizel, T.M., Eds.; CABI: Wallingford, UK, 2017; pp. 449-459.

56. Kodad, O.; Socias, I.C.R.; Alonso, J.M. Genotypic and Environmental Effects on Tocopherol Content in Almond. Antioxidants 2018, 7, 6. [CrossRef] [PubMed]

57. Hyson, D.A.; Schneeman, B.O.; Davis, P.A. Almonds and almond oil have similar effects on plasma lipids and LDL oxidation in healthy men and women. J. Nutr. 2002, 132, 703-707. [CrossRef] [PubMed]

58. Bento, A.P.; Cominetti, C.; Simoes Filho, A.; Naves, M.M. Baru almond improves lipid profile in mildly hypercholesterolemic subjects: A randomized, controlled, crossover study. Nutr. Metab. Cardiovasc. Dis. NMCD 2014, 24, 1330-1336. [CrossRef] [PubMed]

59. Liu, Y.; Hwang, H.J.; Kim, H.S.; Park, H. Time and Intervention Effects of Daily Almond Intake on the Changes of Lipid Profile and Body Composition among Free-Living Healthy Adults. J. Med. Food 2018, 21, 340-347. [CrossRef] [PubMed]

60. Zibaeenezhad, M.J.; Ostovan, P.; Mosavat, S.H.; Zamirian, M.; Attar, A. Almond oil for patients with hyperlipidemia: A randomized open-label controlled clinical trial. Complement. Ther. Med. 2019, 42, 33-36. [CrossRef]

61. Jenkins, D.J.; Kendall, C.W.; Josse, A.R.; Salvatore, S.; Brighenti, F.; Augustin, L.S.; Ellis, P.R.; Vidgen, E.; Rao, A.V. Almonds decrease postprandial glycemia, insulinemia, and oxidative damage in healthy individuals. J. Nutr. 2006, 136, 2987-2992. [CrossRef]

62. Cohen, A.E.; Johnston, C.S. Almond ingestion at mealtime reduces postprandial glycemia and chronic ingestion reduces hemoglobin $\mathrm{A}(1 \mathrm{c})$ in individuals with well-controlled type 2 diabetes mellitus. Metab. Clin. Exp. 2011, 60, 1312-1317. [CrossRef]

63. Dhillon, J.; Thorwald, M.; De La Cruz, N.; Vu, E.; Asghar, S.A.; Kuse, Q.; Diaz Rios, L.K.; Ortiz, R.M. Glucoregulatory and Cardiometabolic Profiles of Almond vs. Cracker Snacking for 8 Weeks in Young Adults: A Randomized Controlled Trial. Nutrients 2018, 10, 960. [CrossRef]

64. Gulati, S.; Misra, A.; Pandey, R.M. Effect of Almond Supplementation on Glycemia and Cardiovascular Risk Factors in Asian Indians in North India with Type 2 Diabetes Mellitus: A 24-Week Study. Metab. Syndr. Relat. Disord. 2017, 15, 98-105. [CrossRef]

65. Li, S.C.; Liu, Y.H.; Liu, J.F.; Chang, W.H.; Chen, C.M.; Chen, C.Y. Almond consumption improved glycemic control and lipid profiles in patients with type 2 diabetes mellitus. Metab. Clin. Exp. 2011, 60, 474-479. [CrossRef] [PubMed]

66. Sabate, J.; Haddad, E.; Tanzman, J.S.; Jambazian, P.; Rajaram, S. Serum lipid response to the graduated enrichment of a Step I diet with almonds: A randomized feeding trial. Am. J. Clin. Nutr. 2003, 77, 1379-1384. [CrossRef] [PubMed] 
67. Lovejoy, J.C.; Most, M.M.; Lefevre, M.; Greenway, F.L.; Rood, J.C. Effect of diets enriched in almonds on insulin action and serum lipids in adults with normal glucose tolerance or type 2 diabetes. Am. J. Clin. Nutr. 2002, 76, 1000-1006. [CrossRef] [PubMed]

68. Scott, L.W.; Balasubramanyam, A.; Kimball, K.T.; Aherns, A.K.; Fordis, C.M., Jr.; Ballantyne, C.M. Long-term, randomized clinical trial of two diets in the metabolic syndrome and type 2 diabetes. Diabetes Care 2003, 26, 2481-2482. [CrossRef] [PubMed]

69. Ren, Y.; Waldron, K.W.; Pacey, J.F.; Brain, A.; Ellis, P.R. Chemical and histochemical characterization of cell wall polysaccharides in almond seeds in relation to lipid bioavailability. In Biologically Active Phytochemicals in Food; Pfannhauser, W., Fenwick, G.R., Khokhar, S., Eds.; Royal Society of Chemistry: Cambridge, UK, 2001; pp. 448-452.

70. Dhillon, J.; Tan, S.Y.; Mattes, R.D. Almond Consumption during Energy Restriction Lowers Truncal Fat and Blood Pressure in Compliant Overweight or Obese Adults. J. Nutr. 2016, 146, 2513-2519. [CrossRef]

71. Foster, G.D.; Shantz, K.L.; Vander Veur, S.S.; Oliver, T.L.; Lent, M.R.; Virus, A.; Szapary, P.O.; Rader, D.J.; Zemel, B.S.; Gilden-Tsai, A. A randomized trial of the effects of an almond-enriched, hypocaloric diet in the treatment of obesity. Am. J. Clin. Nutr. 2012, 96, 249-254. [CrossRef]

72. Berryman, C.E.; West, S.G.; Fleming, J.A.; Bordi, P.L.; Kris-Etherton, P.M. Effects of daily almond consumption on cardiometabolic risk and abdominal adiposity in healthy adults with elevated LDL-cholesterol: A randomized controlled trial. J. Am. Heart Assoc. 2015, 4, e000993. [CrossRef]

73. Chen, C.Y.; Holbrook, M.; Duess, M.A.; Dohadwala, M.M.; Hamburg, N.M.; Asztalos, B.F.; Milbury, P.E.; Blumberg, J.B.; Vita, J.A. Effect of almond consumption on vascular function in patients with coronary artery disease: A randomized, controlled, cross-over trial. Nutr. J. 2015, 14, 61. [CrossRef]

74. Jalali-Khanabadi, B.A.; Mozaffari-Khosravi, H.; Parsaeyan, N. Effects of almond dietary supplementation on coronary heart disease lipid risk factors and serum lipid oxidation parameters in men with mild hyperlipidemia. J. Altern. Complement. Med. 2010, 16, 1279-1283. [CrossRef]

75. Jenkins, D.J.; Kendall, C.W.; Marchie, A.; Parker, T.L.; Connelly, P.W.; Qian, W.; Haight, J.S.; Faulkner, D.; Vidgen, E.; Lapsley, K.G.; et al. Dose response of almonds on coronary heart disease risk factors: Blood lipids, oxidized low-density lipoproteins, lipoprotein(a), homocysteine, and pulmonary nitric oxide: A randomized, controlled, crossover trial. Circulation 2002, 106, 1327-1332. [CrossRef]

76. Nishi, S.; Kendall, C.W.; Gascoyne, A.M.; Bazinet, R.P.; Bashyam, B.; Lapsley, K.G.; Augustin, L.S.; Sievenpiper, J.L.; Jenkins, D.J. Effect of almond consumption on the serum fatty acid profile: A dose-response study. Br. J. Nutr. 2014, 112, 1137-1146. [CrossRef] [PubMed]

77. Wien, M.; Bleich, D.; Raghuwanshi, M.; Gould-Forgerite, S.; Gomes, J.; Monahan-Couch, L.; Oda, K. Almond consumption and cardiovascular risk factors in adults with prediabetes. J. Am. Coll. Nutr. 2010, 29, 189-197. [CrossRef] [PubMed]

78. Rajaram, S.; Connell, K.M.; Sabate, J. Effect of almond-enriched high-monounsaturated fat diet on selected markers of inflammation: A randomised, controlled, crossover study. Br. J. Nutr. 2010, 103, 907-912. [CrossRef] [PubMed]

79. Jia, X.; Li, N.; Zhang, W.; Zhang, X.; Lapsley, K.; Huang, G.; Blumberg, J.; Ma, G.; Chen, J. A pilot study on the effects of almond consumption on DNA damage and oxidative stress in smokers. Nutr. Cancer 2006, 54, 179-183. [CrossRef] [PubMed]

80. Li, N.; Jia, X.; Chen, C.Y.; Blumberg, J.B.; Song, Y.; Zhang, W.; Zhang, X.; Ma, G.; Chen, J. Almond consumption reduces oxidative DNA damage and lipid peroxidation in male smokers. J. Nutr. 2007, 137, 2717-2722. [CrossRef] [PubMed]

81. Jamshed, H.; Gilani, A.U.; Sultan, F.A.; Amin, F.; Arslan, J.; Ghani, S.; Masroor, M. Almond supplementation reduces serum uric acid in coronary artery disease patients: A randomized controlled trial. Nutr. J. 2016, 15, 77. [CrossRef] [PubMed]

82. Phung, O.J.; Makanji, S.S.; White, C.M.; Coleman, C.I. Almonds have a neutral effect on serum lipid profiles: A meta-analysis of randomized trials. J. Am. Diet. Assoc. 2009, 109, 865-873. [CrossRef]

83. Musa-Veloso, K.; Paulionis, L.; Poon, T.; Lee, H.Y. The effects of almond consumption on fasting blood lipid levels: A systematic review and meta-analysis of randomised controlled trials. J. Nutr. Sci. 2016, 5, e34. [CrossRef] 
84. Farzaei, M.H.; Singh, A.K.; Kumar, R.; Croley, C.R.; Pandey, A.K.; Coy-Barrera, E.; Kumar Patra, J.; Das, G.; Kerry, R.G.; Annunziata, G.; et al. Targeting Inflammation by Flavonoids: Novel Therapeutic Strategy for Metabolic Disorders. Int. J. Mol. Sci. 2019, 20, 4957. [CrossRef]

85. Lankisch, P.G.; Otto, J. Salivary isoamylase in duodenal aspirates. Dig. Dis. Sci. 1986, 31, 1299-1302. [CrossRef]

86. Kawamori, R.; Katsura, M.; Ishida, S.; Yamasaki, Y.; Tujii, M.; Kawano, S.; Kamada, T. Subclinical exocrine pancreatic derangement in human diabetic patients evaluated from pure pancreatic juice. J. Diabetes Complicat. 1995, 9, 69-73. [CrossRef]

87. Garrido, I.; Monagas, M.; Gómez-Cordovés, C.; Bartolomé, B. Polyphenols and antioxidant properties of almond skins: Influence of industrial processing. J. Food Sci. 2008, 73, C106-C115. [CrossRef] [PubMed]

88. Milbury, P.E.; Chen, C.Y.; Dolnikowski, G.G.; Blumberg, J.B. Determination of flavonoids and phenolics and their distribution in almonds. J. Agric. Food Chem. 2006, 54, 5027-5033. [CrossRef] [PubMed]

89. Chen, C.-Y.O.; Milbury, P.E.; Blumberg, J.B. Polyphenols in Almond Skins after Blanching Modulate Plasma Biomarkers of Oxidative Stress in Healthy Humans. Antioxidants 2019, 8, 95. [CrossRef]

90. Mandalari, G.; Bisignano, C.; D'Arrigo, M.; Ginestra, G.; Arena, A.; Tomaino, A.; Wickham, M.S. Antimicrobial potential of polyphenols extracted from almond skins. Lett. Appl. Microbiol. 2010, 51, 83-89. [CrossRef]

91. Musarra-Pizzo, M.; Ginestra, G.; Smeriglio, A.; Pennisi, R.; Sciortino, M.T.; Mandalari, G. The Antimicrobial and Antiviral Activity of Polyphenols from Almond (Prunus dulcis L.) Skin. Nutrients 2019, 11, 2355. [CrossRef]

92. Faustino, M.; Veiga, M.; Sousa, P.; Costa, E.M.; Silva, S.; Pintado, M. Agro-Food Byproducts as a New Source of Natural Food Additives. Molecules 2019, 24, 1056. [CrossRef]

93. Teets, A.S.; Were, L.M. Inhibition of lipid oxidation in refrigerated and frozen salted raw minced chicken breasts with electron beam irradiated almond skin powder. Meat Sci. 2008, 80, 1326-1332. [CrossRef]

94. Prasetyo, M.; Chia, M.; Hughey, C.; Were, L.M. Utilization of electron beam irradiated almond skin powder as a natural antioxidant in ground top round beef. J. Food Sci. 2007, 73, T1-T6. [CrossRef]

95. Wijeratne, S.S.K.; Amarowicz, R.; Shahidi, F. Antioxidant activity of almonds and their by-products in food model systems. J. Am. Oil Chem. Soc. 2006, 83, 223-230. [CrossRef]

96. Liu, Z.; Lin, X.; Huang, G.; Zhang, W.; Rao, P.; Ni, L. Prebiotic effects of almonds and almond skins on intestinal microbiota in healthy adult humans. Anaerobe 2014, 26, 1-6. [CrossRef] [PubMed]

97. Ukhanova, M.; Wang, X.; Baer, D.J.; Novotny, J.A.; Fredborg, M.; Mai, V. Effects of almond and pistachio consumption on gut microbiota composition in a randomised cross-over human feeding study. Br. J. Nutr. 2014, 111, 2146-2152. [CrossRef] [PubMed]

98. Mandalari, G.; Faulks, R.M.; Bisignano, C.; Waldron, K.W.; Narbad, A.; Wickham, M.S. In vitro evaluation of the prebiotic properties of almond skins (Amygdalus communis L.). FEMS Microbiol. Lett. 2010, 304, 116-122. [CrossRef] [PubMed]

(C) 2020 by the authors. Licensee MDPI, Basel, Switzerland. This article is an open access article distributed under the terms and conditions of the Creative Commons Attribution (CC BY) license (http://creativecommons.org/licenses/by/4.0/). 